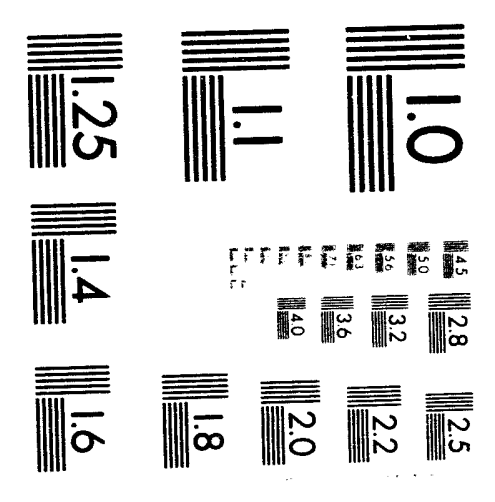




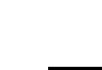
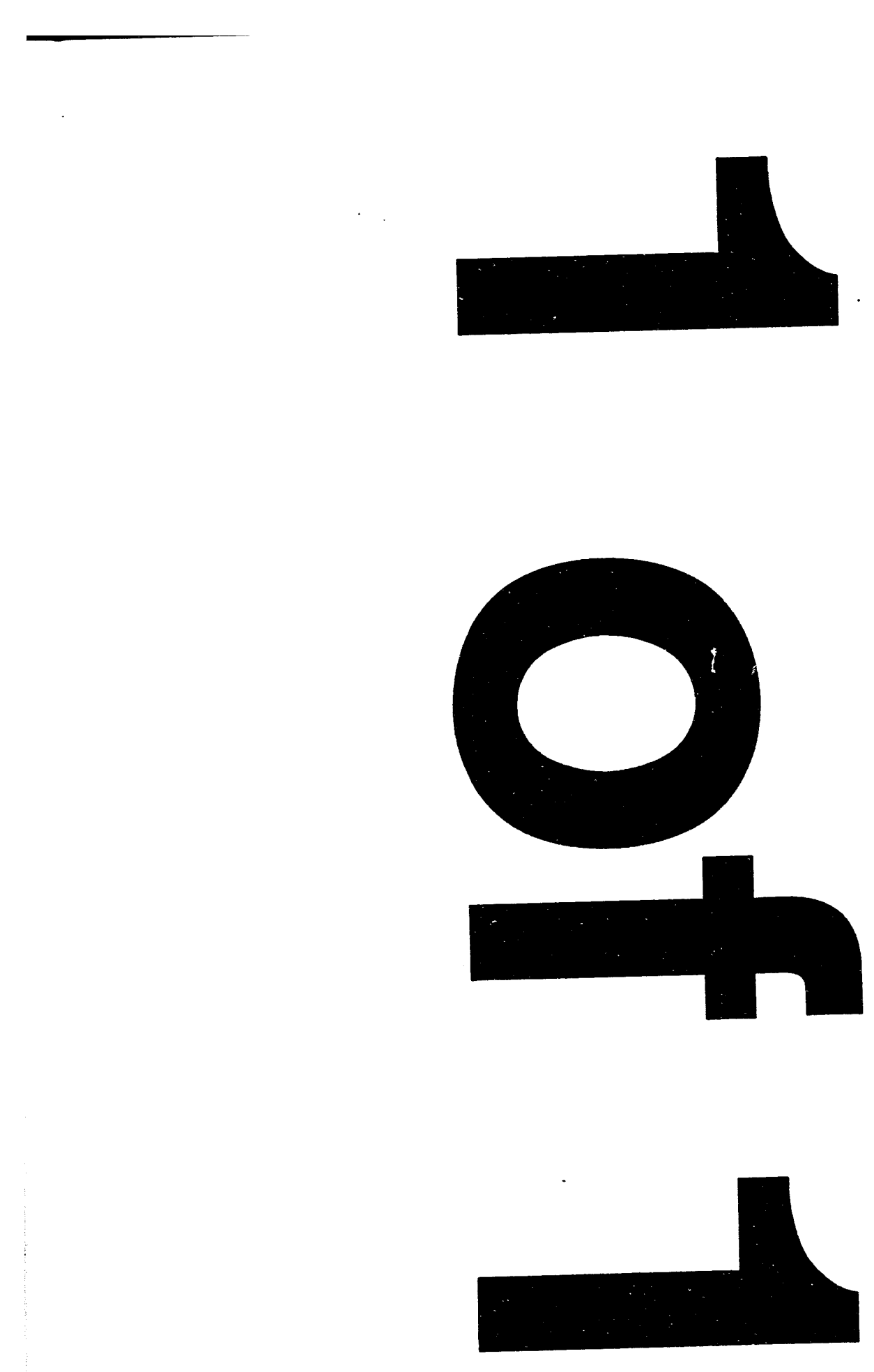
Engineering Physics and Mathematics Division

\title{
APPLICATIONS OF MONTE CARLO METHODS FOR THE ANALYSIS OF MHTGR CASE OF THE VHTRC BENCHMARK
}

\author{
F. C. Difilippo
}

Date Published: March 1994

Research sponsored by the Office of Nuclear Energy U.S. Department of Energy

Prepared by the

OAK RIDGE NATIONAL LABORATORY

Oak Ridge, Tennessee 37831 managed by

MARTIN MARIETTA ENERGY SYSTEMS, INC.

for the

U.S. Department of Energy

under contract DE-AC05-84OR21400 


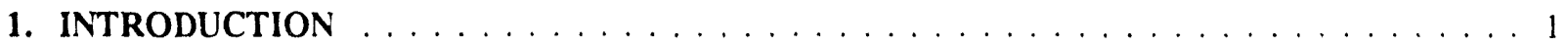

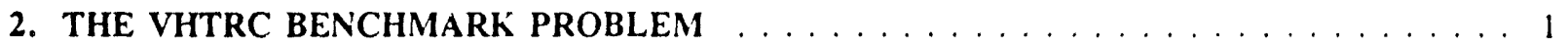

2.1 RESULTS FROM THE CALCULATION OF THE UNIT CELL . . . . . . . . 1

2.2 RESULTS FROM THE CALCULATIONS OF THE WHOLE REACTOR . . . . . 4

3. RESULTS FOR THE CALCULATION OF THE EFFECTIVE DELAYED NEUTRON

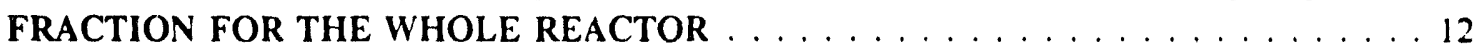

4. COMPARISON WITH OTHER CALCULATIONS $\ldots \ldots \ldots \ldots \ldots \ldots \ldots$

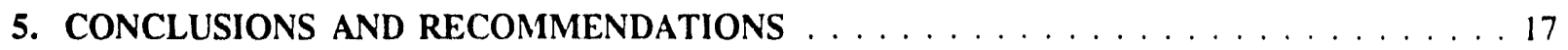

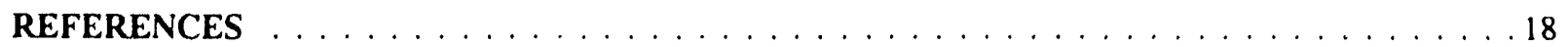

Appendix A. FISSION RATES OF ${ }^{235}$ U AND ${ }^{238}$ U ALONG THE COORDINATES AXIS $\ldots$ A-1 


\section{LIST OF TABLES}

Table 1. $4 \%$ enriched VHI-HP unit cell. Parameters of MCNP runs $\ldots \ldots \ldots \ldots \ldots$

Table 2. $4 \%$ enriched VHI-HP unit cell critical parameters $\ldots \ldots \ldots \ldots \ldots$

Table 3. $4 \%$ enriched VHl-VP unit cell reaction rates for $B^{2}=B_{c}^{2} \ldots \ldots \ldots \ldots$

Table 4. $4 \%$ enriched VH1-HP unit cell spectral indices for $B^{2}=B_{c}^{2} \ldots \ldots \ldots \ldots$

Table 5. Whole reactor calculators. Parameters of MCNP runs $\ldots \ldots \ldots \ldots \ldots$

Table 6. Whole reactor calculations. Critical parameters. $\ldots \ldots \ldots \ldots \ldots \ldots$

Table 7. Whole reactor calculation. Reaction rates at the center of the core for the heterogeneous compact model $\ldots \ldots \ldots \ldots \ldots \ldots$

Table 8. Whole reactor calculators. Spectral indices at the center of the core for the

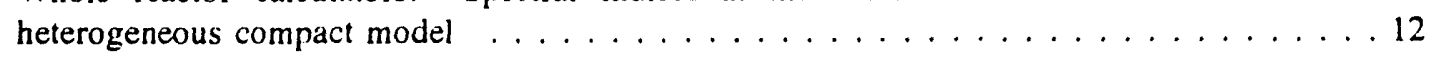

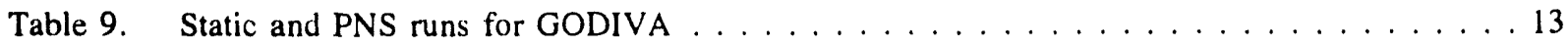

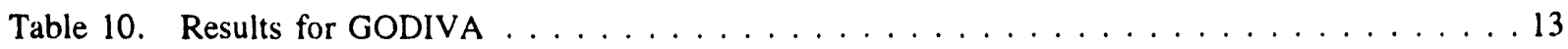

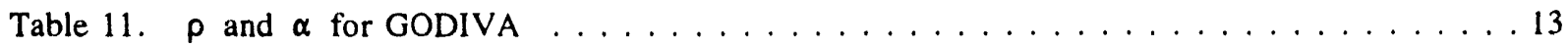

Table 12. Determination of $\Lambda$ and $\beta$ for GodIVA $\ldots \ldots \ldots \ldots \ldots \ldots$

Table 13. VH1-HP whole reactor. Effect of changing $10_{\mathrm{B}}$ concentration. $\ldots \ldots \ldots \ldots \ldots$

Table 14. Intercomparison of cell parameter for VH1-HP $\ldots \ldots \ldots \ldots \ldots$

Table 15. Intercomparison of capture rates in cell calculations for VHI-HP $\ldots \ldots \ldots \ldots$

Table 16. Intercomparison of fission rates in cell calculations for $\mathrm{VH} 1-\mathrm{HP} \ldots \ldots \ldots$

Table 17. Intercomparison of spectral indices in cell calculation for VH1-HP $\ldots \ldots \ldots \ldots$

Table 18. Intercomparison of whole reactor $k$ for VHl-HP $\ldots \ldots \ldots \ldots \ldots$

Table A.1. VH1HP (homogeneous compact) ${ }^{235} \mathrm{U}$ fission $\ldots \ldots \ldots \ldots \ldots \ldots \ldots$

Table A.2. VH1HP (homogeneous compact) ${ }^{235} \mathrm{U}$ fission $\ldots \ldots \ldots \ldots \ldots \ldots \ldots$. . . . . A

Table A.3. VH1HP (heterogeneous compact) ${ }^{235} \mathrm{U}$ fission $\ldots \ldots \ldots \ldots \ldots \ldots$

Table A.4. VH1HP (homogeneous compact) ${ }^{238} \mathrm{U}$ fission. MCNP 500,000. HIST $x$-axis

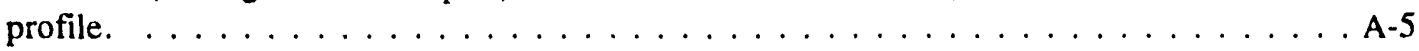

Table A.5. VH1HP (homogeneous compact ${ }^{238} \mathrm{U}$ fission. MCNP 500,000. HIST y-axis

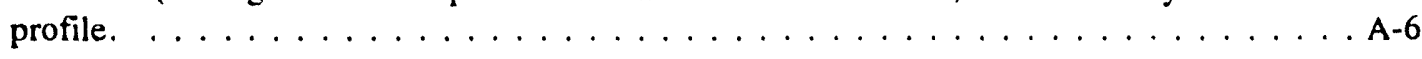

Table A.6. VH1HP (heterogeneous compact) ${ }^{238} \mathrm{U}$ fission $\ldots \ldots \ldots \ldots \ldots \ldots \ldots$ 


\section{LIST OF FIGURES}

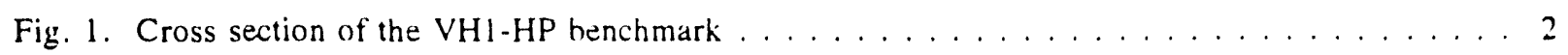

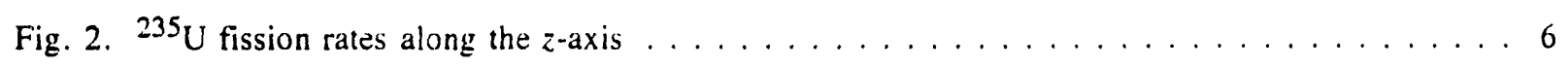

Fig. 3. ${ }^{238} \mathrm{U}$ fission rates along the $z$-axis $\ldots \ldots \ldots \ldots \ldots \ldots \ldots \ldots \ldots$

Fig. 4. ${ }^{235} \mathrm{U}$ fission rates along the $x$-axis $\ldots \ldots \ldots \ldots \ldots \ldots \ldots$

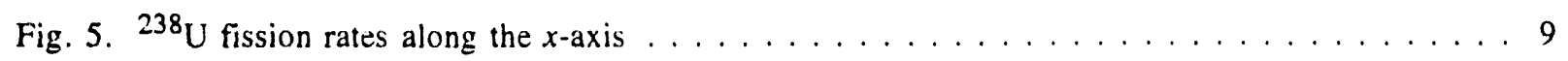

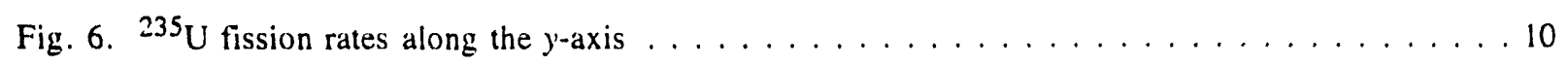

Fig. 7. ${ }^{238} \mathrm{U}$ fission rates along the $y$-axis $\ldots \ldots \ldots \ldots \ldots \ldots \ldots \ldots \ldots$

Fig. 8. VH1-HP configuration with 20 times the nominal ${ }^{10} \mathrm{~B}$ concentration in the graphite; results

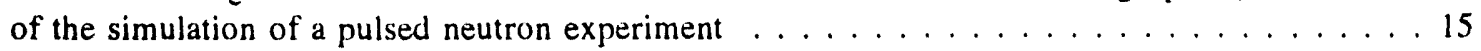




\title{
APPLICATIONS OF MONTE CARLO METHODS FOR THE ANALYSIS OF MHTGR CASE OF THE VHTRC BENCHMARK
}

\author{
Felix C. Difilippo
}

\section{INTRODUCTION}

Monte Carlo methods, as implemented in the MCNP code, have been used to analyze the neutronics characteristics of benchmarks related to Modular High Temperature Gas-Cooled Reactors. The benchmarks are idealized versions of the Japanese (VHTRC) and Swiss (PROTEUS) facilities and an actual configurations of the PROTEUS Configuration I experiment. The purpose of the unit cell benchmarks is to compare multiplication constants, critical bucklings, migration lengths, reaction rates and spectral indices. The purpose of the full reactors benchmarks is to compare multiplication constants, reaction rates, spectral indices, neutron balances, reaction ra $\mathrm{s}$ profiles, temperature coefficients of reactivity and effective delayed neutron fractions. All of these parameters can be calculated by MCNP, which can provide a very detailed model of the geometry of the configurations, from fuel particles to entire fuel assemblies, using at the same time a continuous energy model. These characteristics make MCNP a very useful tool to analyze these MHTGR benchmarks.

We have used the MCNP latest version, 4.x, eld $=01 / 12 / 93$ with an ENDF/B-V cross section library. This library does not yet contain temperature dependent resonance materials, so all calculations correspond to room temperature, $\mathrm{T}=300^{\circ} \mathrm{K}$. Two separate reports were made-one for the VHTRC, the other for the PROTEUS benchmark.

\section{THE VHTRC BENCHMARK PROBLEM}

The calculations shown here correspond to the specifications of benchmark VH1-HP as described in Ref. 1. Twelve fuel elements contain $124 \% \mathrm{U}^{235}$ enriched fuel rods which are made of fuel particles in a graphite matrix. Figure 1 shows the distribution of the fuel elements inside the graphite reflector. The fuel extension in the axial direction is $1454 \mathrm{~mm}$ (two adjacent halves of $727 \mathrm{~mm}$ ) with $473 \mathrm{~mm}$ thick axial graphite reflectors at both ends.

\subsection{RESULTS FROM THE CALCULATION OF THE UNIT CELL}

The unit cell corresponding to the core region of Fig. 1 consists of a hexagonal piece of graphite $(300 \mathrm{~mm}$ flat to flat) with 12 fuel rods located in positions of a $65 \mathrm{~mm}$ pitch hexagonal lattice. The MCNP calculations were done for an infinite two-dimensional l.exagonal lattice with each position filled with a unit cell with infinite axial dimensions. To consider double heterogeneity effects, two types of calculations were done: (1) one with homogenized fuel compact isotope densities (in a volumetric sense) (i.e,, to consider only one heterogeneity effect), and (2) the other with an explicit representation of the individual fuel particles (i.e., to consider both heterogeneity effects). These calculations are going to be named homogenized and heterogeneous compact for short.

In order to run the heterogeneous compact calculations, it was assumed that the fuel particles are arranged in a cubic lattice whose cell size is given by the average number of fuel particles per unit volume. Each fuel particle was explicitly defined in terms of its components: fuel kernel, first and second coating layers, and graphite matrix. Note that with this model, MCNP calculates the interactions of the neutrons with all the cell components from fuel particles to the graphite moderator. The parameters of the calculations for the unit cells with MCNP are shown in Table 1. Although, there is a factor of 7 for the CPU time required for the heterogeneous calculation with respect to the homogeneous case, it is possible to represent explicitly all the heterogeneities of the system and to obtain reasonable statistical precision in a reasonable amount of time. 


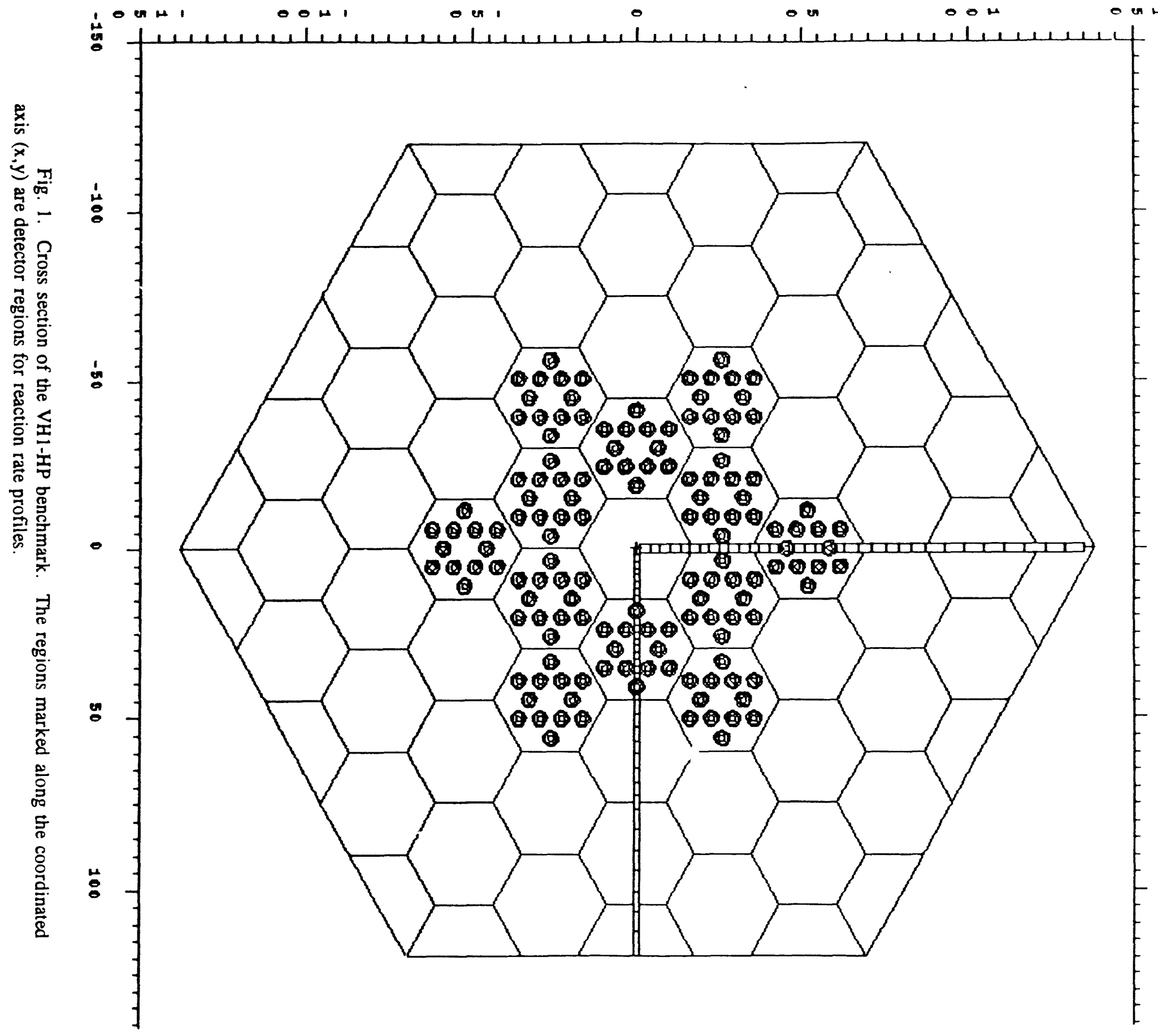


Table 1. 4\% enriched V'HI-HP unit cell. Parameters of MCNP runs

\begin{tabular}{|l|c|c|}
\hline & Homogenized compact & Heterogenerous compact \\
\hline Number of generations & 100 & 100 \\
\hline Neutrons per generation & 500 & 500 \\
\hline Total number of histories & 50,000 & 50,000 \\
\hline CPU time for IBM workstation (minutes) & 78 & 540 \\
\hline
\end{tabular}

Results for critical parameters, reaction rates and spectral indices are shown respectively in Tables 2, 3 , and 4 , together with their statistical uncertainties when these are available. In each case, two calculations were done, one with the cell occupying the whole space and the other with the hexagonal lattice intercepted with a sphere of radius $107.10 \mathrm{~cm}$, very near to what later became the critical radius. Reaction rates and spectral indices quoted as corresponding to $B^{2}=B_{c}^{2}$ were calculated for this sphere.

Table 2. $4 \%$ enriched VHI-HP unit cell critical parameters

\begin{tabular}{||l|c|c|}
\hline \multicolumn{1}{|c|}{ Parameter } & Homogenized compact & Heterogeneous compact \\
\hline$k_{\infty}\left(B^{2}=0\right)$ & $i .47801 \pm 0.00280$ & $1.50159 \pm 0.00305$ \\
\hline$k_{\infty}\left(B^{2}=B_{c}^{2}\right)$ & $1.42164 \pm 0.00416$ & $1.44401 \pm 0.00401$ \\
\hline Critical $B_{c}^{2}\left(m^{-2}\right)$ & $7.645 \pm 0.098$ & $7.836 \pm 0.100$ \\
\hline Migration Length M $(\mathrm{cm})$ & $23.4841 \pm 0.1948$ & $23.8042 \pm 0.1851$ \\
\hline Radius critical sphere $(\mathrm{cm})$ & $110.80 \pm 0.71$ & $109.41 \pm 0.71$ \\
\hline
\end{tabular}

Table 3. $4 \%$ enriched VHI-VP unit cell reaction rates for $B^{2}=B_{c}^{2}$ a

\begin{tabular}{|c|c|c|c|c|}
\hline \multirow{2}{*}{ Isotope } & \multicolumn{2}{|c|}{ Fissions/Absorptions } & \multicolumn{2}{c|}{ Capture/Absorptions } \\
\cline { 2 - 5 } & $\begin{array}{c}\text { Homogenerous } \\
\text { Compact }\end{array}$ & $\begin{array}{c}\text { Heterogenerous } \\
\text { Compact }\end{array}$ & $\begin{array}{c}\text { Homogenerous } \\
\text { Compact }\end{array}$ & $\begin{array}{c}\text { Heterogenerous } \\
\text { Compact }\end{array}$ \\
\hline${ }^{235} \mathrm{U}$ & $5.7907 \mathrm{E}-1$ & $5.8817 \mathrm{E}-1$ & $1.1331 \mathrm{E}-1$ & $1.1447 \mathrm{E}-1$ \\
\hline${ }^{238} \mathrm{U}$ & $4.0179 \mathrm{E}-3$ & $4.2256 \mathrm{E}-3$ & $2.6264 \mathrm{E}-1$ & $2.5181 \mathrm{E}-1$ \\
\hline $236 \mathrm{U}$ & $5.7260 \mathrm{E}-6$ & $3.8873 \mathrm{E}-6$ & $3.7960 \mathrm{E}-4$ & $3.0366 \mathrm{E}-4$ \\
\hline $234 \mathrm{U}$ & $3.7010 \mathrm{E}-6$ & $2.0484 \mathrm{E}-5$ & $1.4300 \mathrm{E}-3$ & $1.2606 \mathrm{E}-3$ \\
\hline $\mathrm{C}$ & - & - & $3.5346 \mathrm{E}-2$ & $3.5967 \mathrm{E}-2$ \\
\hline $\mathrm{N}$ & - & - & $2.1910 \mathrm{E}-3$ & $2.2640 \mathrm{E}-3$ \\
\hline${ }^{10} \mathrm{~B}$ & - & - & $8.6340 \mathrm{E}-4$ & $7.2668 \mathrm{E}-4$ \\
\hline $\mathrm{H}$ & - & - & $4.3840 \mathrm{E}-4$ & $4.4470 \mathrm{E}-4$ \\
\hline 0 & - & - & $1.9960 \mathrm{E}-4$ & $2.1879 \mathrm{E}-4$ \\
\hline${ }^{11} \mathrm{~B}$ & - & - & $1.3976 \mathrm{E}-11$ & $5.8436 \mathrm{E}-10$ \\
\hline
\end{tabular}

a Statistical uncertainties depend on reaction rates. For this 50,000 histories run, the errors are a fraction of one percent for captures in ${ }^{235} \mathrm{U}$ and ${ }^{238} \mathrm{U}$ and fissions in ${ }^{235} \mathrm{U}$, around $1 \%$ for captures in $\mathrm{C}$, several percents for fissions in ${ }^{238} \mathrm{U}$ and very large for captures in ${ }^{11} \mathrm{~B}$. 
Table 4. $4 \%$ enriched VH1-HP unit cell spectral indices ${ }^{a}$ for $B^{2}=B_{c}^{2}$

\begin{tabular}{||c|c|c|}
\hline Spectral index & Homogeneous compact & Heterogenerous compact \\
\hline $\begin{array}{l}\rho^{28} ; \text { Ratio epithermal to thermal } \\
\text { captures in }{ }^{238} \mathrm{U}\end{array}$ & 3.179 & 2.980 \\
\hline $\begin{array}{l}\delta^{25}: \text { Ratio epithermal to thermal } \\
\text { fission in } 235 \mathrm{U}\end{array}$ & 0.07738 & 0.07698 \\
\hline $\begin{array}{l}\delta^{28}: \text { Ratio of macroscopic }{ }^{238} \mathrm{U} \\
\text { to }{ }^{235} \mathrm{U} \text { fissions }\end{array}$ & 0.006897 & 0.007061 \\
\hline $\begin{array}{l}\text { C*: Ratio of macroscopic } 238 \mathrm{U} \\
\text { captures to } 235 \mathrm{U} \text { fissions }\end{array}$ & 0.4571 & 0.4356 \\
\hline
\end{tabular}

a These values correspond to reaction rates for those regions where the isotopes are present in the reactor, i.e., the fuel particles, statistical error is $1 \%$.

\subsection{RESULTS FROM THE CALCULATIONS OF THE WHOLE REACTOR}

The $(x, y)$ cross section of the whole reactor is shown in Fig. 1. Two sets of calculations were done-one with the homogenized compact, the other with the explicit modeling of the fuel particles and the end caps of the fuel rods. Table 5 summarizes the parameters of the MCNP calculations.

Table 5. Whole reactor calculators. Parameters of MCNP runs.

\begin{tabular}{||l|c|c|}
\hline & Homogeneous compact & Heterogeneous compact \\
\hline \hline Number of generations & 100 & 100 \\
\hline Neutrons per generations & 5,000 & 5,000 \\
\hline Total number of histories & 500,000 & 500,000 \\
\hline Number of cells for detector materials & 69.0 & 71.0 \\
\hline CPU time for IBM workstations & 1.29 days & 3.13 days \\
\hline
\end{tabular}

Table 6 shows multiplication constants and neutron balance integrated over the whole reactor together with the experimental value for $k$ as quoted in Ref. 1. 
Table 6. Whole reactor calculations. Critical parameters.

\begin{tabular}{||l|c|c|c|}
\hline & Homogeneous compact & Heterogeneous compact & Experiment \\
\hline \hline$k$ & $1.00499 \pm 0.00116$ & $1.01131 \pm 0.00110$ & 1.008 \\
\hline Leakage/Absorption $^{\mathrm{a}}$ & 0.32471 & 0.32819 & NA \\
\hline Production/Absorption $^{\mathrm{a}}$ & 1.33132 & 1.34321 & NA \\
\hline
\end{tabular}

a Reactor average.

The agreement with the experimental value of $k$ is very good. The heterogeneous compact calculations agree within $+0.33 \%$; also, the difference between heterogeneous and homogeneous compact calculations is $0.63 \%$, similar to the value quoted in Ref. 1 .

Table 7 summarizes the reaction rates of nuclides present in the system for the central region of the core as defined in the table. Table 8 summarizes the spectral indices for the same region. The values of Tables 7 and 8 are from the heterogeneous compact calculations.

Figures 2 through 7 show the fission reaction rates for ${ }^{235} \mathrm{U}$ and ${ }^{238} \mathrm{U}$ along the coordinates axis of Fig. 1. The axial reaction rates are averages in the central graphite and the $x$ and $y$ reaction rates are averages in the regions shown in Fig. 1 extended from -20 to $20 \mathrm{~cm}$ in the $z$-direction. The fission rates are tabulated in Appendix A.

The axial reaction rates of Figs. 2 and 3 are from the heterogeneous compact calculations while the (x,y) profiles are from the homogeneous compact calculations. The axial profiles along the $z$ axis is smooth whereas the reaction rates in the $(x, y)$ plane are very sensitive to the proximity of the fuel rods as Figs. 4 through 7 show.

Table 7. Whole reactor calculation. Reaction rates ${ }^{a}$ at the center of the core for the heterogeneous compact model

\begin{tabular}{|c|c|c|}
\hline Isotope & Fissions/absorption & Captures/absorptions \\
\hline${ }^{235} \mathrm{U}$ & $6.1998 \mathrm{E}-1(0.7 \%)$ & $1.1889 \mathrm{E}-1(3.4 \%)$ \\
\hline${ }^{238} \mathrm{U}$ & $3.5040 \mathrm{E}-3(5 \%)$ & $2.1160 \mathrm{E}-1(2.6 \%)$ \\
\hline${ }^{236} \mathrm{U}$ & $9.7009 \mathrm{E}-7(\sim 100 \%)$ & $1.1256 \mathrm{E}-4$ \\
\hline${ }^{234} \mathrm{U}$ & $8.4102 \mathrm{E}-6$ & $2.8468 \mathrm{E}-3$ \\
\hline $\mathrm{C}$ & - & $3.8750 \mathrm{E}-2(2.2 \%)$ \\
\hline $\mathrm{N}$ & - & $2.9018 \mathrm{E}-3$ \\
\hline${ }^{10} \mathrm{~B}$ & - & $3.7022 \mathrm{E}-4$ \\
\hline $\mathrm{H}$ & - & $4.1488 \mathrm{E}-4$ \\
\hline $\mathrm{O}$ & - & $2.4467 \mathrm{E}-4$ \\
\hline${ }^{11} \mathrm{~B}$ & - & $\mathrm{O}^{\mathrm{b}}$ \\
\hline
\end{tabular}

a Reaction rates are for a $10 \mathrm{~cm}$ height slab of the fuel element located to the right of the central graphite of Fig. 1. The slab is located between 0.5 and $10.5 \mathrm{~cm}$ with respect to the center of the reactor and includes the 12 fuel rods and the graphite. Statistical errors depend on reaction rates; some are shown.

b For the 500,00 histories sampling. 


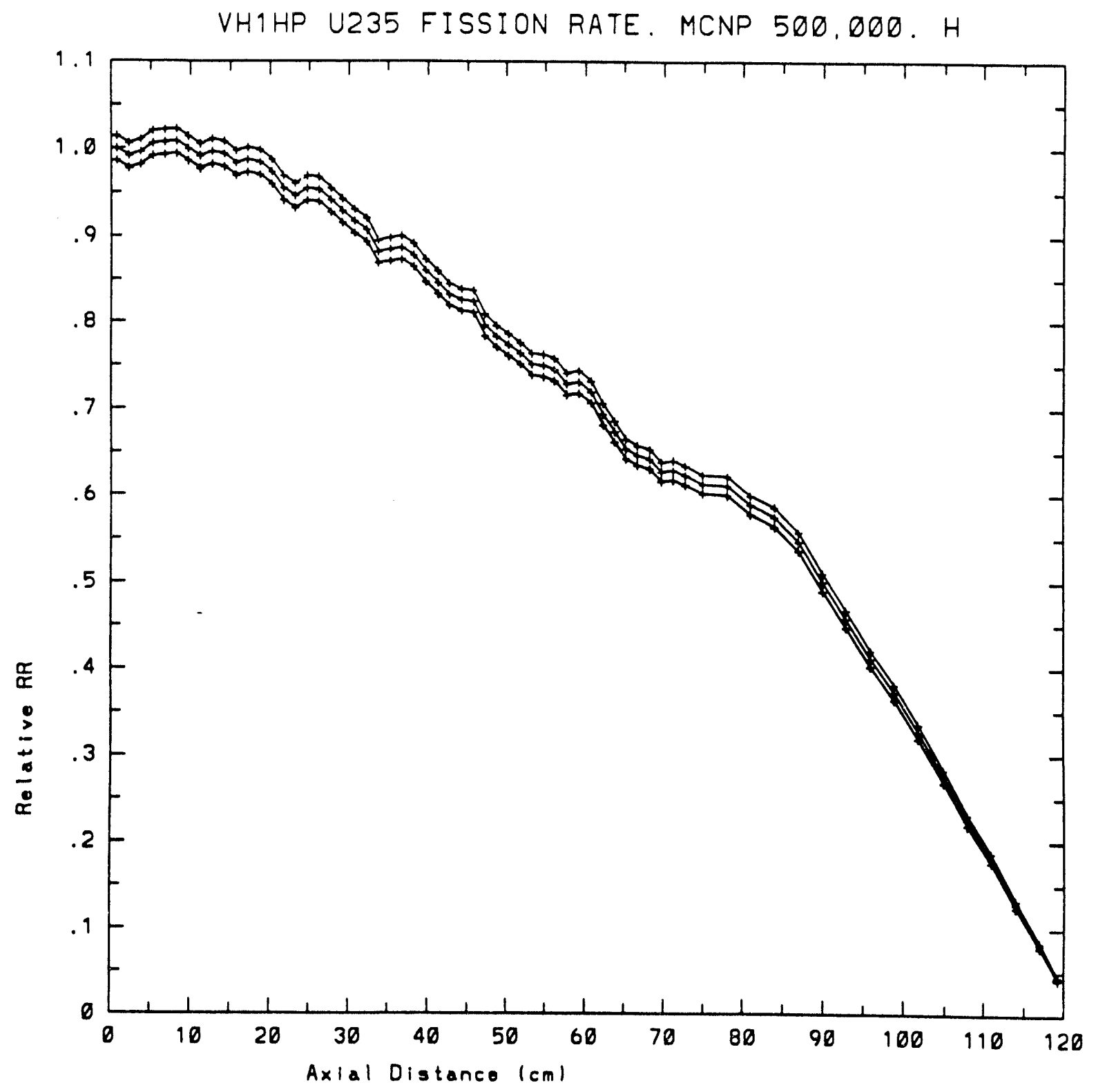

Fig. 2. ${ }^{235} U$ fission rates along the $z$-axis, extreme curves show the uncertainties (1 sigma). 


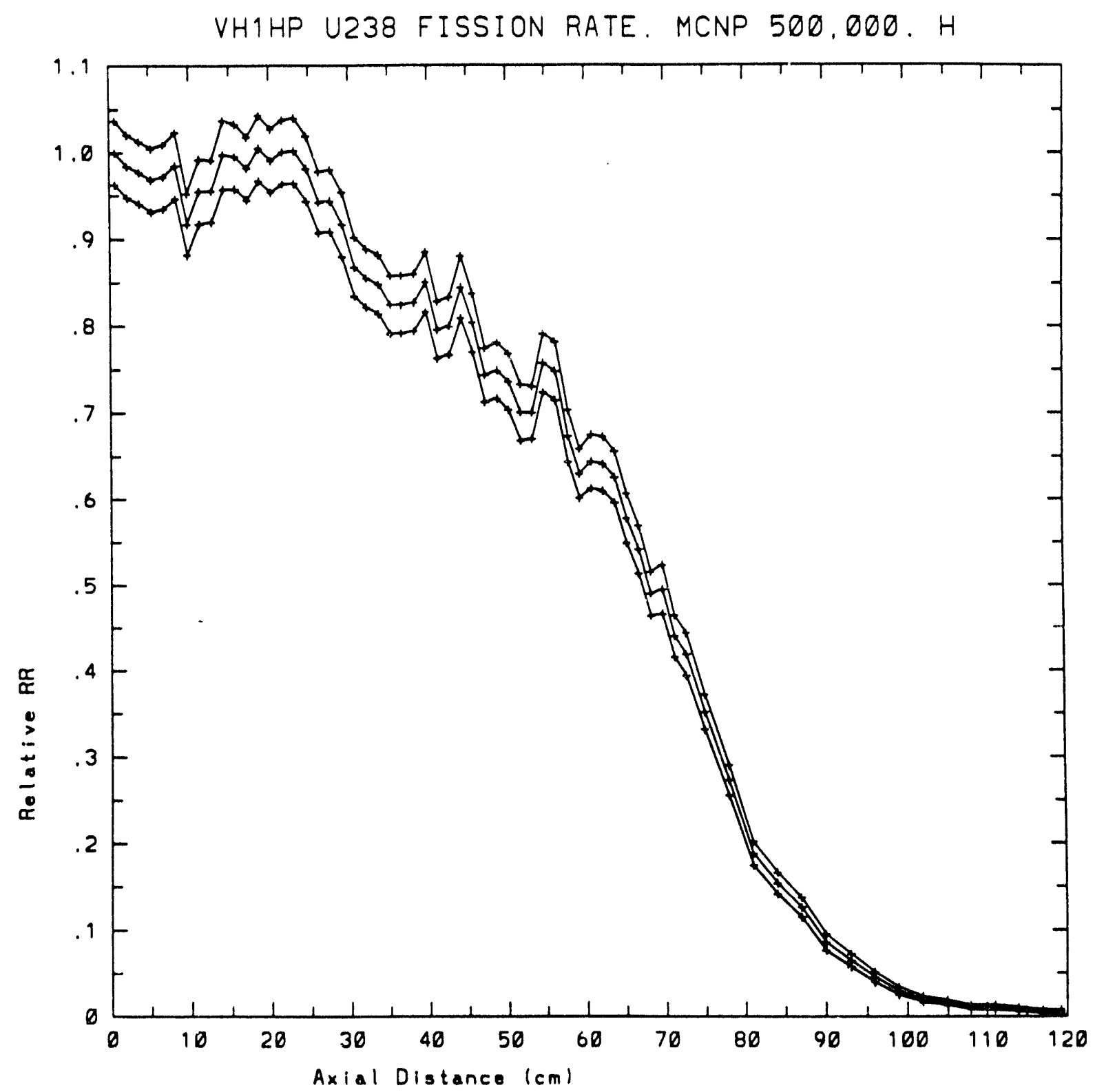

Fig. 3. ${ }^{238} \mathrm{U}$ fission rates along the $z$-axis, extreme curves show the uncertainties (1 sigma). 


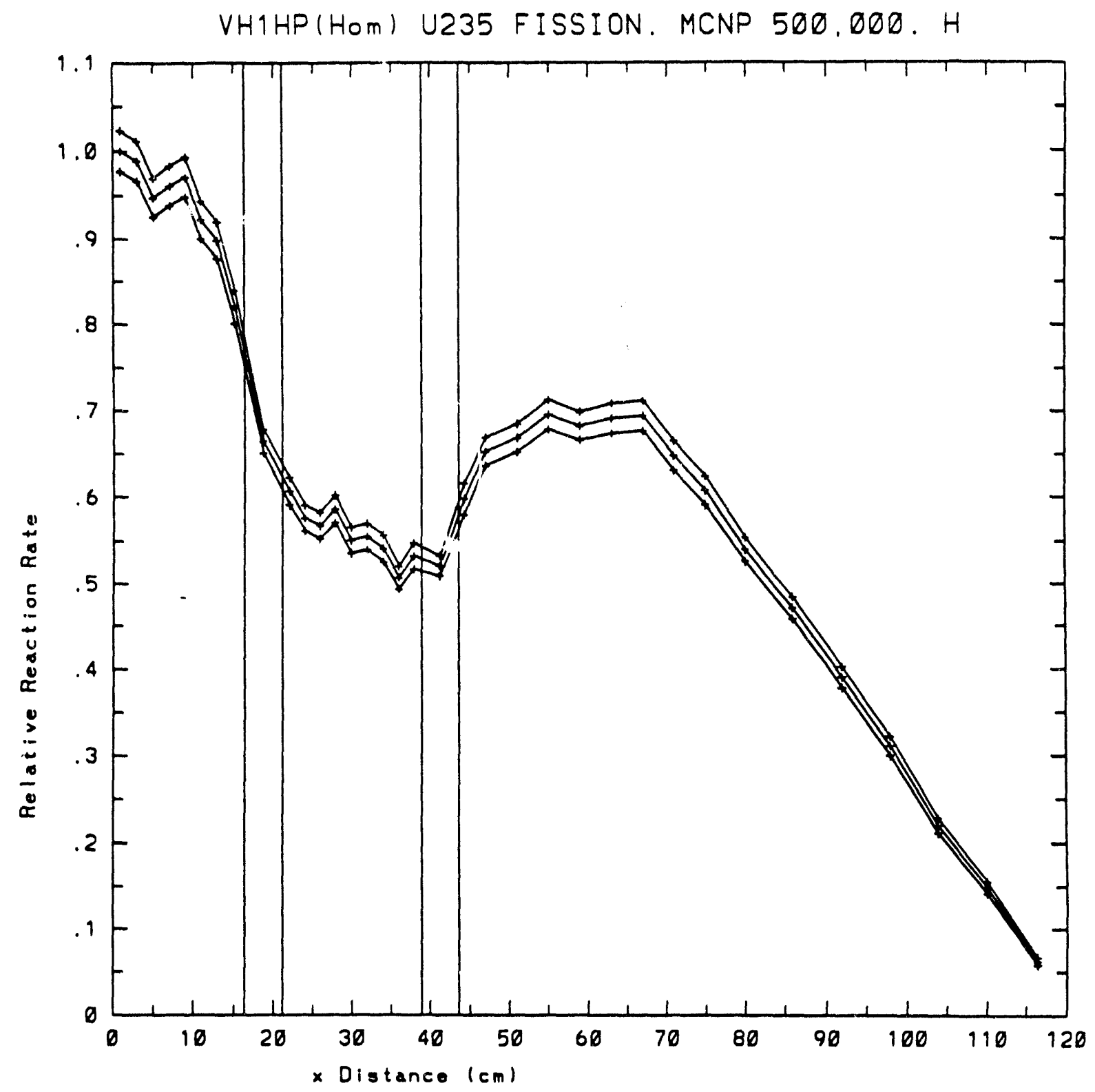

Fig. 4. ${ }^{205} U$ fission rates along the $x$-axis, extreme curves show the uncertainties (1 sigma). The vertical lines indicate the two fuel rods crossed in this direction. 


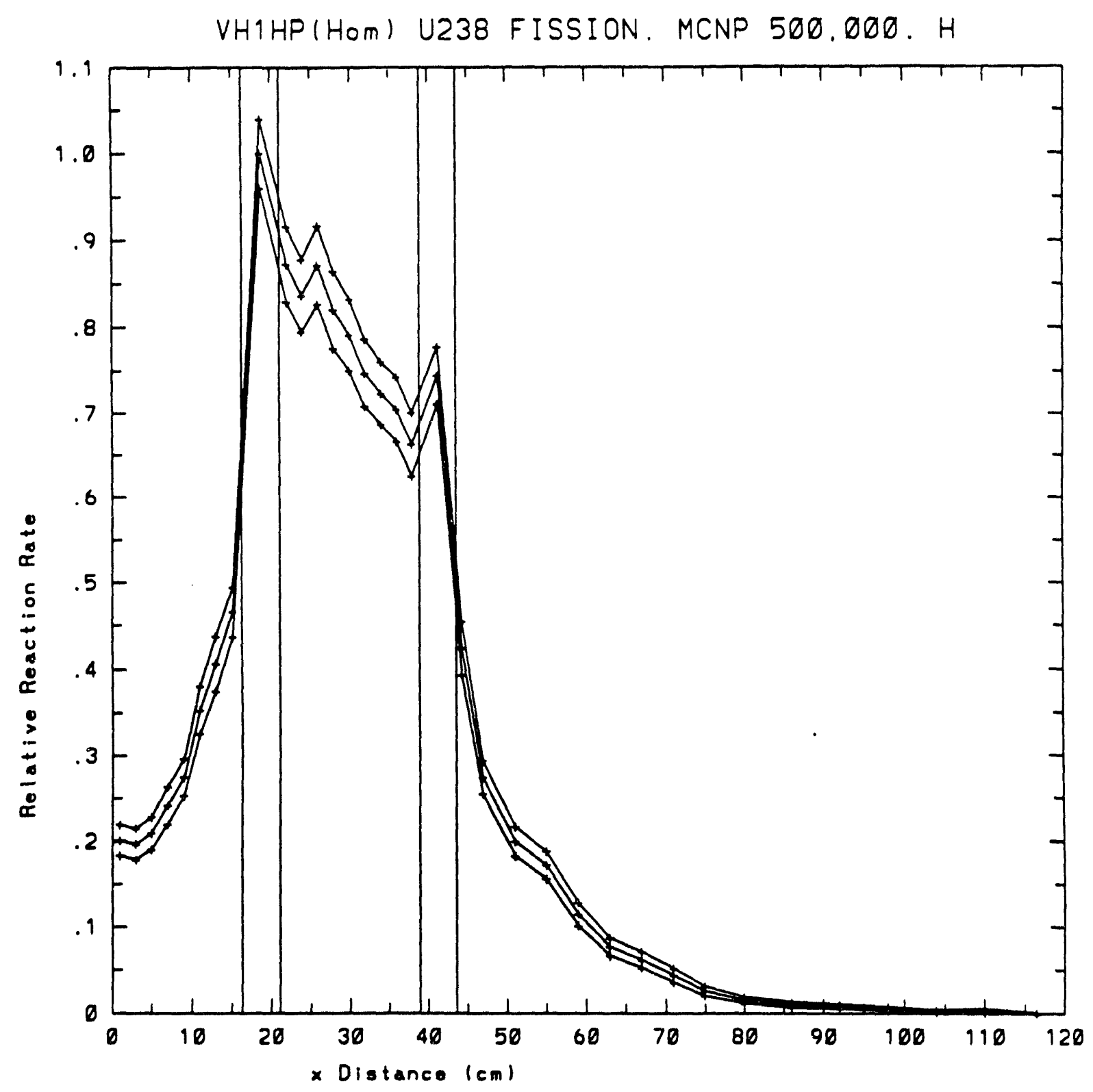

Fig. 5. ${ }^{238} \mathrm{U}$ fission rates along the $x$-axis, extreme curves show the uncertainties (1 sigma). The vertical lines indicate the two fuel rods crossed in this direction. 


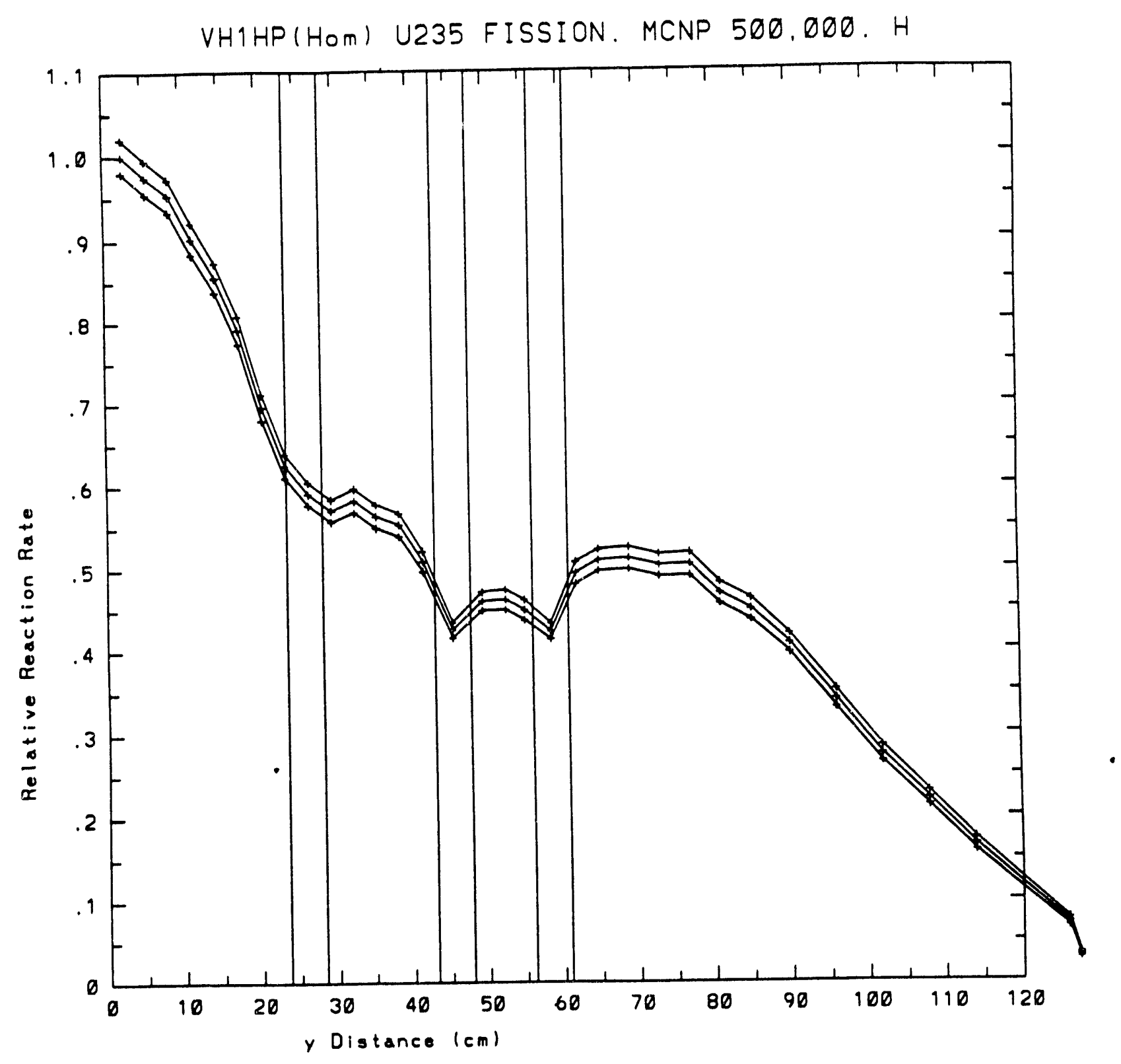

Fig. 6. ${ }^{25} \mathrm{U}$ fission rates along the $y$-axis, the extreme curves show the uncertainties (1 sigma). The vertical lines indicate the fuel rods near (the one at $\sim 25 \mathrm{~cm}$ ) or crossed (the other two) in this direction. 


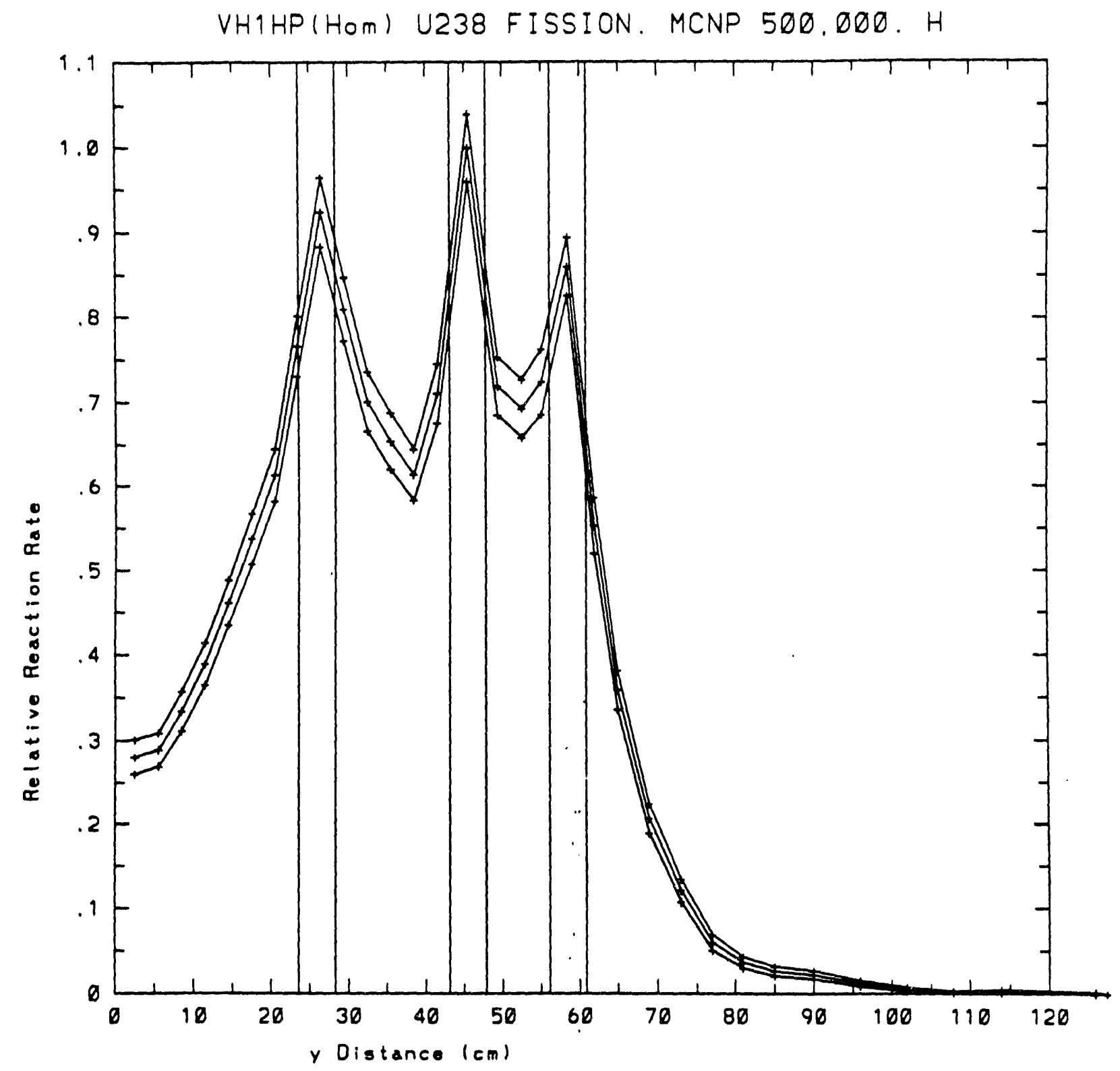

Fig. 7. ${ }^{238} \mathrm{U}$ fission rates along the $y$-axis, the extreme curves show the uncertainties (1 sigma). The vertical lines indicate the fuel rods near (the one at $-25 \mathrm{~cm}$ ) or crossed (the other two) in this direction. 
Table 8. Whole reactor calculators. Spectral indices ${ }^{a}$ at the center of the core for the heterogeneous compact model

\begin{tabular}{|c|c|}
\hline Spectral index & Value (\% error) \\
\hline \hline$\rho^{28}$ & $2.054(4.3 \%)$ \\
\hline$\delta^{25}$ & $0.05594(2.5 \%)$ \\
\hline$\delta^{28}$ & $0.005886(2.7 \%)$ \\
\hline$C^{*}$ & $0.3383(3.3 \%)$ \\
\hline
\end{tabular}

a Values correspond to reaction rates in regions where the isotopes are present in the region (i.e., the fuel particles).

\section{RESULTS FOR THE CALCULATION OF THE EFFECTIVE DELAYED NEUTRON FRACTION FOR THE WHOLE REACTOR}

One of the requests of the benchmark is the calculation of the dollar unit, the effective delayed neutron fraction, this can be done with MCNP because it has the capability to calculate the response of the system to the injection of a pulse of neutrons. The time dependent reaction rate can then be fit to an exponential decay to determine the prompt decay constant $\alpha$, which is related to the multiplication factor, $k$ by the inhour equation:

$$
\rho=\alpha \wedge-\beta f(\alpha)
$$

where $\rho$ is the reactivity in absolute units, $\rho=(1-k) / k, \Lambda=\ell / k$ is the generation time, $\Lambda$ and $\beta$ ar? effective values,

$$
f(\alpha)=\alpha \sum_{i=1}^{6} \frac{a_{i}}{\alpha-\lambda_{i}}
$$

and $a_{i}$ are the relative production of neutrons for delayed group $i$. If. for two states with equal $l / k$, we compute $\rho$ and $\alpha, \beta$ and $\Lambda$ can be obtained from Eq. (1). If more states are available, a fit of Eq. (1) would improve the accuracy. The condition for this method is to calculate states with equal $\ell / k$, condition that can be checked because MCNP inakes also an estimation of the mean life of the neutrons $\ell$.

Because of its simplicity and fast spectra, the Godiva configuration was chosen to test this method for the calculation $\beta$. The short lifetime of the neutrons makes the MCNP run particularly fast.

Static (for $\rho$ ) and pulsed neutron source (PNS) (for $\alpha$ ) runs were made for the GODIVA configuration with different radius listed in Table 9 (which includes also typical CPU times). 
Table 9. Static and PNS runs for GODIVA

\begin{tabular}{|c|c|c|c|c|}
\hline \multirow{2}{*}{ Radius (cm) } & \multicolumn{2}{|c|}{ Static } & \multicolumn{2}{c|}{ PNS } \\
\cline { 2 - 5 } & Histories & CPU (min) & Histories & CPU (min) \\
\hline \hline 8.0 & $800,000.0$ & 14.0 & $100,000.0$ & 86.0 \\
\hline 8.5 & $800,000.0$ & 15.0 & 100.000 .0 & 317.0 \\
\hline 8.62 & $800,000.0$ & 16.0 & $100,000.0$ & 553.0 \\
\hline
\end{tabular}

The reactivity was changed by changing the radius with the results summarized in Table 10 .

Table 10. Results for GODIVA

\begin{tabular}{|c|c|c|c|}
\hline Radius $(\mathrm{cm})$ & $k$ & $\ell$ (nsec) & $\ell / k$ (nsec) \\
\hline \hline 8.0 & $0.92570 \pm 0.00075$ & $5.20 \pm 0.01$ & 5.62 \\
\hline 8.5 & $0.97405 \pm 0.00066$ & $5.5 ? \pm 0.01$ & 5.67 \\
\hline 8.62 & $0.98610 \pm 0.00068$ & $5.61 \pm 0.01$ & 5.69 \\
\hline
\end{tabular}

Table 10 shows that $\wedge$ is fairly constant for this example. Note that the $P$ of Table 9 is an estimator computed by MCNP by following the fate of the neutrons while the $\ell$ and $\Lambda$ of Eq. (1) are averages weighted with static adjoint fluxes: although very useful to check the constancy of $\Lambda$, the $P$ from MCNP calculations do not have to be confused with the kinetic $\ell$ of Eq. (1).

With the $\rho$ of Table 10 and the $\alpha$ 's from the fit of the PNS runs we have the results of Table 11 .

Table 11. $\rho$ and $\alpha$ for GODIVA

\begin{tabular}{|c|c|c|}
\hline $\mathbf{R}(\mathbf{c m})$ & $\rho(\%$ error $)$ & $\alpha\left(\mathrm{sec}^{-1}\right)$ \\
\hline \hline 8.0 & $0.080264(1.1)$ & $16,418,460.0 \pm 47191.0$ \\
\hline 8.5 & $0.026641(2.6)$ & $6.172,705.0 \pm 13143.0$ \\
\hline 8.62 & $0.014096(5.0)$ & $3,939,115.0 \pm 8757.0$ \\
\hline
\end{tabular}

Note that the method relies on the calculation of $\rho$ whose errors are difficult to reduce when the system approaches criticality. With the values of Table 11 and considering that for GODIVA $f(\alpha)$ in Eq. (1) is equal to $1, \wedge$ and $\beta$ can be determined by a linear square fit; results are in Table 12. 
Table 12. Determination of $\Lambda$ and $\beta$ for GODIVA

\begin{tabular}{|ll|}
$\Lambda=(5.284 \pm 0.087)$ nsec & $(1.6 \%)$ \\
$\beta=0.00638 \pm 0.00080$ & $(12.5 \%)$ \\
$\alpha_{8}=\frac{\beta}{\Lambda}=1,207,975 \pm 168,718$ & $(14.0 \%)$ \\
\hline
\end{tabular}

For this case, the inverse of the effective generation time $\left(\alpha_{g}\right)$ is equal to the prompt decay constant at delay critical. The value for $\beta$ is smaller than the nuclear $\beta$, result we should expect for this fast system; statistical errors are, anyway, large and mainly reflect the large errors of $\rho$ near critical.

Some preliminary calculations were done to apply this technique for the VH1-HP benchmark. The reactivity was changed by changing the amount of equivalent ${ }^{10} \mathrm{~B}$ impurities in the graphite outside the fuel rods; the nominal ${ }^{10} \mathrm{~B}$ impurities in the calculations of Table 6 is $1.54 \mathrm{ppm}\left({ }^{10} \mathrm{~B}\right.$ atoms per million atoms in the mixture). This number was increased by a factor of 20 with the results shown in Table 13.

Table 13. VH1-HP whole reactor. Effect of changing ${ }^{10} \mathrm{~B}$ concentration.

Results from heterogeneous compact calculations

\begin{tabular}{|l|c|}
\hline $\mathrm{C}=10_{\mathrm{B}}$ concentration $(\mathrm{ppm})$ in graphite & $k$ \\
\hline 1.54 (nominal) & $1.01131 \pm 0.00110$ \\
\hline $30.80(20$ times nominal) & $0.98382 \pm 0.00374$ \\
\hline$\Delta k / \Delta C=-93.9 \mathrm{pcm} / \mathrm{ppm}\left(1 \mathrm{pcm}=\Delta \mathrm{k}^{*} 100,000.0\right)$ & \\
\hline
\end{tabular}

The pulsed neutron source experiment was simulated then for the subcritical system of Table 13 (i.e., including fuel particles explicitly) with the results shown in Fig. 8. The fit of this data gives $\alpha=(14.24 \pm 0.67) \mathrm{sec}^{-1}$. Because MCNP mimics the fate of the neutrons in the real reactor, the calculations of the PNS experiment are particularly slow for graphite reactors near critical; for this $1.6 \%$ subcritical case it was required 8.8 days of the CPU time of an IBM workstation to compute the time profile.

\section{COMPARISON WITH OTHER CALCULATIONS}

Similar calculations were made by other laboritories, namely General Atomic (GA) in the U.S., Japan Energy Research Institute (JAERI), and the Kurchatov Institute in Russia. The results were obtained from Ref. 2 and compared here with our calculations.

Table 14 shows the values for the critical parameters of the $4 \%$ enriched VH1-HP cell. Tables 15 and 16 show reaction rates for the cell materials, Table 17 for the spectral indices, and Table 18 values for whole reactor calculations. Our discrepancy with the measured $k$ is $+0.35 \%$ very similar to the average discrepancy quoted by GA in Ref. 2 . 


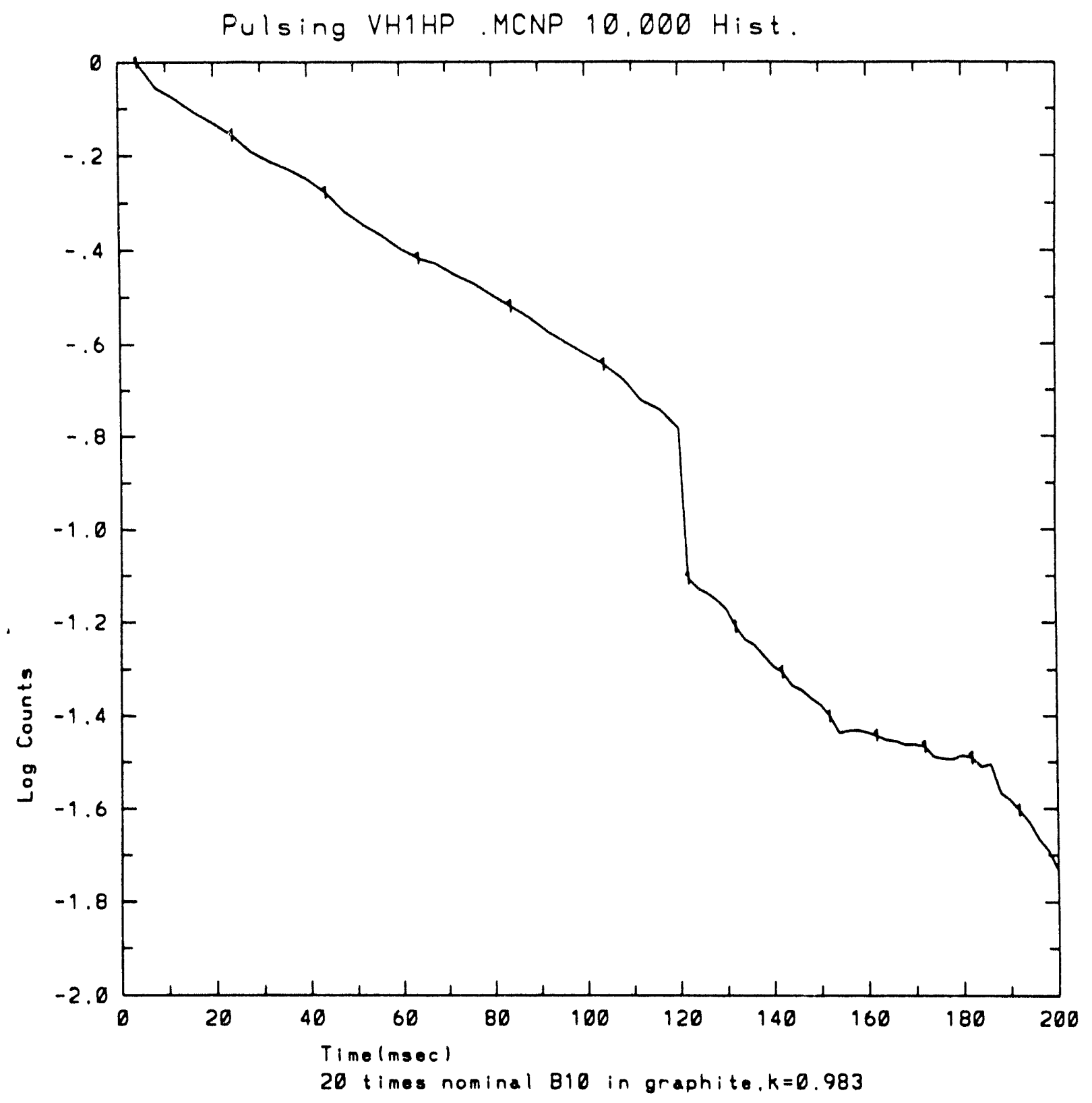

Fig. 8. VH1-HP configuration with 20 tines the nominal ${ }^{10} \mathrm{~B}$ concentration in the graphite; results of the simulation of a pulsed neutron experiment. Note at $120 \mathrm{msec}$ the reduction, by a factor of 2 , of the channel width $\Delta t$. 
Table 14. Interemparison of cell parameter for VH1-HP

\begin{tabular}{|c|c|c|c|}
\hline Parameter & This work & GA & JAERI $^{\mathrm{h}}$ \\
\hline \hline$k_{\infty}\left(B^{2}=0\right)$ & $1.50159 \pm 0.00305$ & 1.5069 & 1.4944 \\
\hline$B_{c}^{2}\left(m^{-2}\right)$ & $7.836 \pm 0.100$ & 8.443 & 8.108 \\
\hline$k_{\infty}\left(B_{c}^{2}\right)$ & $1.44401 \pm 0.00401$ & 1.45 .48 & 1.4436 \\
\hline$M^{2}\left(\mathrm{~cm}^{2}\right)$ & $566.640 \pm 8.812$ & 538.6 & 547.1 \\
\hline
\end{tabular}

${ }^{a}$ From Table $2, \mathrm{~T}=26.85^{\circ} \mathrm{C}\left(300^{\circ} \mathrm{K}\right)$.

${ }^{b}$ Values were interpolated for $\mathrm{T}=26.85^{\circ} \mathrm{C}$.

Table 15. Intercomparison of capture rates in cell calculations for VHI-HP

\begin{tabular}{|c|c|c|c|}
\hline Nuclide & This work & GA $^{\mathbf{b}}$ & JAERI $^{\mathbf{b}}$ \\
\hline${ }^{234} \mathrm{U}$ & $1.261-3$ & $1.551-3$ & $1.420-3$ \\
\hline $235 \mathrm{U}$ & $1.145-1(0.5 \%)$ & $1.158-1$ & $1.154-1$ \\
\hline${ }^{236} \mathrm{U}$ & $3.0374-4$ & $3.433-4$ & $3.345-4$ \\
\hline${ }^{238} \mathrm{U}$ & $2.518-1(0.5 \%)$ & $2.467-1$ & $2.471-1$ \\
\hline${ }^{1} \mathrm{H}$ & $4.447-4$ & $4.256-4$ & $4.336-4$ \\
\hline${ }^{10} \mathrm{~B}$ & $7.267-4$ & $7.327-4$ & $7.394-4$ \\
\hline${ }^{12} \mathrm{C}$ & $3.597-2(1.2 \%)$ & $3.506-2$ & $3.557-2$ \\
\hline${ }^{14} \mathrm{~N}$ & $2.264-3$ & $2.616-3$ & $2.631-3$ \\
\hline${ }^{16} \mathrm{O}$ & $2.188-4$ & $2.061-4$ & $1.990-4$ \\
\hline
\end{tabular}

${ }^{a}$ At $\mathrm{T}=26.85^{\circ} \mathrm{C}$ and from Table 3 , some statistical error shown.

$\mathrm{b}_{\text {At }} \mathrm{T}=25.5^{\circ} \mathrm{C}$ (corrections for $\Delta \mathrm{T}$ are negligible).

Table 16. Intercomparison of fission rates in cell calculations for VH1-HP

\begin{tabular}{|c|c|c|c|}
\hline Nuclide & This work $^{\mathbf{a}}$ & GA $^{\mathbf{b}}$ & JAERI $^{\mathbf{b}}$ \\
\hline \hline${ }^{234} \mathrm{U}$ & $2.048-5(6 \%)$ & $1.167-5$ & $7.025-6$ \\
\hline${ }^{235} \mathrm{U}$ & $5.882-1(0.2 \%)$ & $5.926-1$ & $5.920-1$ \\
\hline${ }^{236} \mathrm{U}$ & $3.887-6$ & $6.512-6$ & $2.294-6$ \\
\hline${ }^{238} \mathrm{U}$ & $4.226-3(7 \%)$ & $3.913-3$ & $4.218-3$ \\
\hline
\end{tabular}

${ }^{\mathrm{a}}$ From Table 3 , at $\mathrm{T}=26.85^{\circ} \mathrm{C}$. Some statistical error shown.

$\mathrm{b}_{\mathrm{At}} \mathrm{T}=25.5^{\circ} \mathrm{C}$ (corrections for $\Delta \mathrm{T}$ are negligible). 
Table 17. Intercomparison of spectral indices in cell calculation for VH1-HP

\begin{tabular}{|l|c|c|c|}
\hline \multicolumn{1}{|c|}{ Parameter } & This work $^{\mathrm{a}}$ & $\mathrm{GA}^{\mathrm{b}}$ & JAERI $^{\mathrm{h}}$ \\
\hline$\rho^{28}$ & 2.980 & 2.776 & 2.823 \\
\hline$\delta^{25}$ & 0.07698 & 0.07232 & 0.07464 \\
\hline$\delta^{28}$ (macro) & 0.007061 & 0.006604 & 0.007128 \\
\hline$C^{*}$ (macro) & 0.4356 & 0.4164 & 0.4173 \\
\hline
\end{tabular}

${ }^{a}$ From Table 4 at $\mathrm{T}=26.85^{\circ} \mathrm{C}$. Reaction rates only in those regions where isotopes are present (i.e., fuel particles), statistical error is $1 \%$.

$\mathrm{b}$ At $\mathrm{T}=25.5^{\circ} \mathrm{C}$ (corrections for $\Delta \mathrm{T}$ are negligible).

Table 18. Intercomparison of whole reactor $k$ for VH1-HP at $\mathrm{T}=25.5^{\circ} \mathrm{C}$

\begin{tabular}{|c|c|}
\hline Experiment & 1.008 \\
\hline This work $^{\mathrm{a}}$ & $1.01154 \pm 0.00110$ \\
\hline GA & 1.0134 \\
\hline JAERI & 1.0162 \\
\hline KI & 1.0167 \\
\hline
\end{tabular}

a From Table 6 and temperature coefficient $-1.73 \times 10^{-4} /{ }^{\circ} \mathrm{C}$ (experimental).

\section{CONCLUSIONS AND RECOMMENDATIONS}

MCNP calculations of the VHTRC benchmark allow unprecedented degree of details in the models not available with other methods. The reactor was modeled in all of its details from the fuel particles $(502$ microns diameter) to the reflector ( $2.4 \mathrm{~m}$ flat to flat) and with continuous energy representation of the cross sections. Details like the end caps of the fuel rods can be modeled exactly with the flexibility of MCNP.

All the requested parameters from the specifications of the benchmarks can be calculated. In addition, pulsed neutron experiments (usual technique at PROTEUS and VHTRC facilities) can be modeled explicitly, so MCNP is going to play a major role in the interpretation of experiments to determine the impurities of the graphite and reactivities. Our results compare very well with respect to the calculations of three independent groups.

The model can be easily improved by the introduction of more details about experimental devices. Required CPU times are large; in a good proportion this is due to the long lifetime of the neutrons in the graphite system, the problem is particularly severe when PNS experiments near critical are simulated. It is strongly recommended then to use the high performance computer resources at ORNL to take advantage of the flexibility of MCNP to work with parallel computers. 


\section{REFERENCES}

1. H. Yasuda, T. Yamana, and K. Tsuchihashi, "VHTRC Temperalure Coefficient Benchmark Problem," presented to the Second Research Coordination Meeting. JAERI-Tokai, May 20-22, 1991.

2. M. Schmidt-Hoenow and R. A. Rucker, "Analysis of VHTRC Physics Benchmar'ks," General Atomics DOE-HTGR-90363, Revision 0 (May 1993). 
Appendix A

FISSION RATES OF ${ }^{235} \mathrm{U}$ AND ${ }^{238} \mathrm{U}$ ALONG THE COORDINATES AXIS

Table A.1. VH1HP (homogeneous compact) ${ }^{235} \mathrm{U}$ fission. MCNP 500,000.

HIST $x$-axis profile

\begin{tabular}{|c|c|c|}
\hline$x(\mathrm{~cm})$ & Fission rate & Relative error \\
\hline 1.00 & 7.77230 E-02 & 0.0227 \\
\hline 3.00 & $7.68734 \mathrm{E}-02$ & 0.0225 \\
\hline 5.00 & 7.36861E-02 & 0.0231 \\
\hline 7.00 & 7.47202E-02 & 0.0229 \\
\hline 9.00 & $7.54846 \mathrm{E}-02$ & 0.0228 \\
\hline 11.00 & 7.17033E-02 & 0.0237 \\
\hline 13.00 & 6.97792E-02 & 0.0238 \\
\hline 15.19 & 6.37887E-02 & 0.0231 \\
\hline 18.74 & $5.16741 \mathrm{E}-02$ & 0.0204 \\
\hline 22.05 & $4.71847 \mathrm{E}-02$ & 0.0255 \\
\hline 24.00 & 4.48024E-02 & 0.0252 \\
\hline 26.00 & 4.41325E-02 & 0.0264 \\
\hline 28.00 & 4.55902E-0 & 0.0268 \\
\hline 30.00 & 4.28101E-02 & 0.0268 \\
\hline 32.00 & 4.31248E-02 & 0.0270 \\
\hline 34.00 & 4.20833E-02 & 0.0287 \\
\hline 36.00 & $3.94038 \mathrm{E}-02$ & 0.0265 \\
\hline 37.94 & 4.13992E-02 & 0.0284 \\
\hline 41.26 & $4.04939 \mathrm{E}-02$ & 0.0226 \\
\hline 44.31 & 4.64662E-02 & 0.0293 \\
\hline 47.00 & 5.07035E-02 & 0.0250 \\
\hline 51.00 & 5.19617E-02 & 0.0241 \\
\hline 55.00 & 5.40387E-02 & 0.0245 \\
\hline 59.00 & $5.30020 \mathrm{E}-02$ & 0.0239 \\
\hline 63.00 & $5.36868 \mathrm{E}-02$ & 0.0251 \\
\hline 67.00 & 5.39071E-02 & 0.0250 \\
\hline 71.00 & $5.03547 \mathrm{E}-02$ & 0.0261 \\
\hline 75.00 & 4.72485E-02 & 0.0270 \\
\hline 80.00 & 4.20110E-02 & 0.0256 \\
\hline 86.00 & $3.66390 \mathrm{E}-02$ & 0.0277 \\
\hline 92.00 & $3.03791 \mathrm{E}-02$ & 0.0305 \\
\hline 98.00 & $2.41918 \mathrm{E}-02$ & 0.0353 \\
\hline 104.00 & 1.70889E-02 & 0.0383 \\
\hline 110.00 & 1.15747E-02 & 0.0469 \\
\hline 116.45 & $4.86974 \mathrm{E}-02$ & 0.0669 \\
\hline
\end{tabular}

A-1 
Table A.2. VHIHP (homogeneous compact) ${ }^{235} \mathrm{U}$ fission. MCNP 500.000. HIST y-axis profile.

\begin{tabular}{|c|c|c|}
\hline$y(\mathrm{~cm})$ & Fission rate & Relative error \\
\hline $2 .$. & 7.79966E-02 & 0.0200 \\
\hline 5.5 & $7.60279 \mathrm{E}-02$ & 0.0203 \\
\hline 8.5 & $7.43555 \mathrm{E} \cdot 02$ & 0.0203 \\
\hline 11.5 & $7.04089 \mathrm{E}-02$ & 0.0206 \\
\hline 14.5 & $6.67824 \mathrm{E}-02$ & 0.0207 \\
\hline 17.5 & $6.17524 \mathrm{E}-02$ & 0.0216 \\
\hline 20.5 & 5.43221E-02 & 0.0227 \\
\hline 23.5 & 4.87779E-02 & 0.0229 \\
\hline 26.5 & $4.61513 \mathrm{E}-02$ & 0.0230 \\
\hline 29.5 & 4.45498E-02 & 0.0235 \\
\hline 32.5 & 4.54822E-02 & 0.0242 \\
\hline 35.5 & 4.39922E-02 & 0.0250 \\
\hline 38.5 & 4.31814E-02 & 0.0248 \\
\hline 41.55 & $3.97484 \mathrm{E}-02$ & 0.0242 \\
\hline 45.46 & 3.31747E-02 & 0.0223 \\
\hline 49.41 & 3.59088E-02 & 0.0249 \\
\hline 52.5 & 3.60592E-02 & 0.0266 \\
\hline 55.05 & 3.50668E-02 & 0.0276 \\
\hline 58.46 & 3.30115E-02 & 0.0233 \\
\hline 61.91 & $3.85681 \mathrm{E}-02$ & 0.0274 \\
\hline 65.00 & $3.97756 \mathrm{E}-02$ & 0.0253 \\
\hline 69.00 & $3.99613 \mathrm{E}-02$ & 0.0260 \\
\hline 73.00 & 3.92755E-02 & $0: 0265$ \\
\hline 77.00 & 3.93843E-02 & 0.0278 \\
\hline 81.00 & 3.66123E-02 & 0.0280 \\
\hline 85.00 & $3.50674 \mathrm{E} \cdot 02$ & 0.0295 \\
\hline 90.00 & $3.17828 E-02$ & 0.0280 \\
\hline 96.00 & 2.65791E-02 & 0.0312 \\
\hline 102.00 & 2.14099E-02 & 0.0356 \\
\hline 108.00 & 1.72037E-02 & 0.0380 \\
\hline 114.00 & 1.29204E-02 & 0.0456 \\
\hline 126.00 & 5.56480E-03 & 0.0663 \\
\hline 132.00 & $2.41523 \mathrm{E}-03$ & 0.0867 \\
\hline
\end{tabular}


Table A.3. VHIHP (heterogeneous compact) ${ }^{235}$ U fission. MCNP 500,000. HIST axial profile.

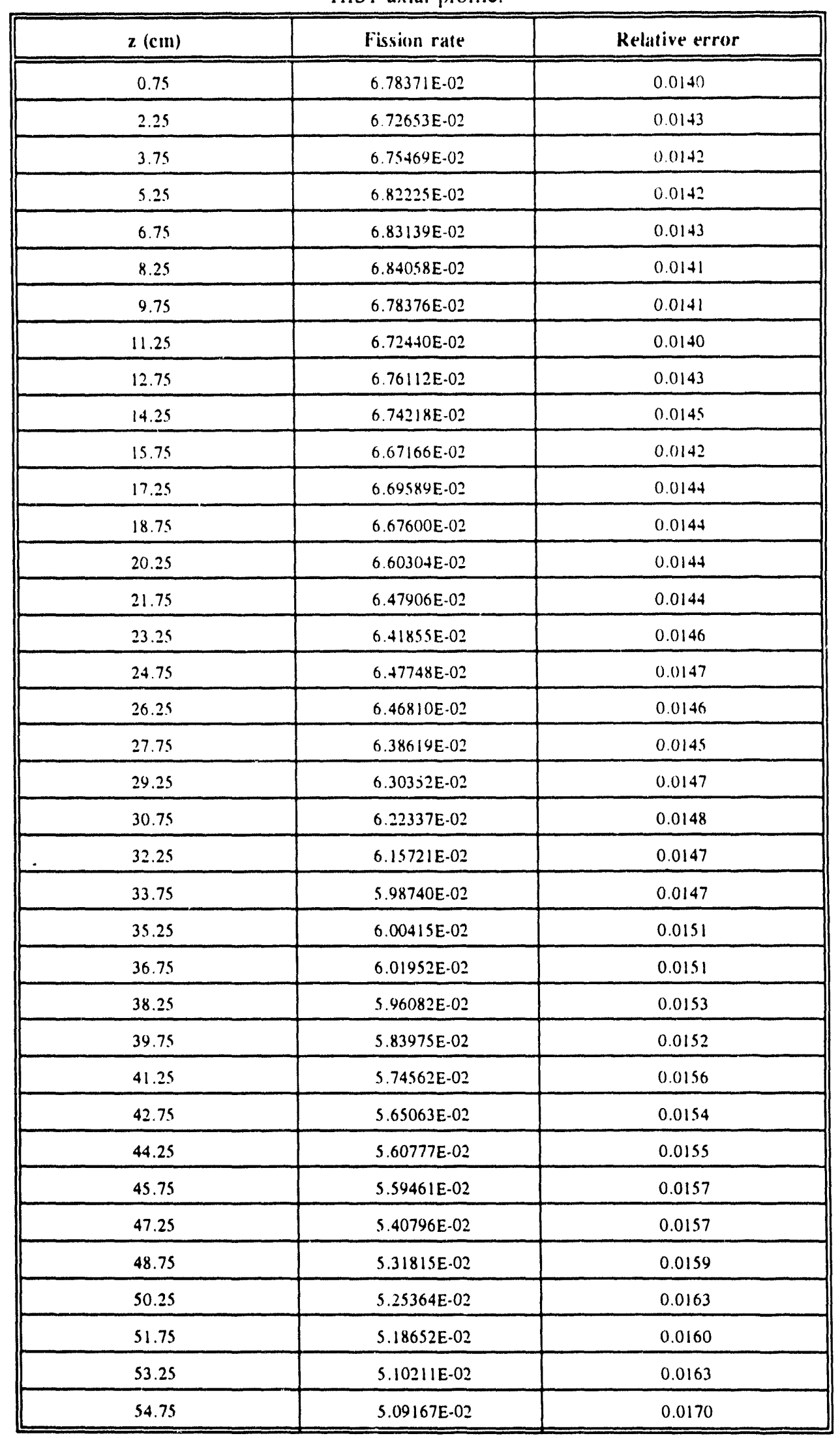


Table A.3. VHIHP (heterogeneous compact) ${ }^{235}$ U fission. MCNP 500,000.

HIST axial profile.

\begin{tabular}{|c|c|c|}
\hline$z(\mathrm{~cm})$ & Fission rate & Relative error \\
\hline 56.25 & $5.06113 \mathrm{E}-02$ & 0.0171 \\
\hline 57.75 & $4.95168 \mathrm{E}-02$ & 0.0169 \\
\hline 59.25 & $4.96408 \mathrm{E}-02$ & 0.0177 \\
\hline 60.75 & 4.88955E-02 & 0.0173 \\
\hline 62.25 & $4.71760 \mathrm{E}-02$ & 0.0173 \\
\hline 63.75 & $4.58272 \mathrm{E}-02$ & 0.0174 \\
\hline 65.25 & $4.44730 \mathrm{E}-02$ & 0.0176 \\
\hline 66.75 & 4.39581E-02 & 0.0176 \\
\hline 68.25 & $4.26645 \mathrm{E}-02$ & 0.0177 \\
\hline 69.75 & 4.16747E-02 & 0.0178 \\
\hline 71.25 & 4.27666E-02 & 0.0180 \\
\hline 72.75 & 4.23654E-02 & 0.0179 \\
\hline 75.00 & $4.16756 \mathrm{E}-02$ & 0.0177 \\
\hline 78.00 & 4.15552E-02 & 0.0181 \\
\hline 81.00 & $4.0042 .4 \mathrm{E}-02$ & 0.0183 \\
\hline 84.00 & $3.90871 \mathrm{E}-02$ & 0.0193 \\
\hline 87.00 & $3.71807 \mathrm{E}-02$ & 0.0198 \\
\hline 90.00 & $3.40156 \mathrm{E}-02$ & 0.0207 \\
\hline 93.00 & $3.11369 \mathrm{E}-02$ & 0.0217 \\
\hline 96.00 & $2.79430 \mathrm{E}-02$ & 0.0226 \\
\hline 99.00 & $2.52870 \mathrm{E} \cdot 02$ & 0.0234 \\
\hline 102.00 & $2.22048 \mathrm{E}-02$ & 0.0250 \\
\hline 105.00 & 1.87439E-02 & 0.0268 \\
\hline 108.00 & $1.53175 \mathrm{E}-02$ & 0.0285 \\
\hline 111.00 & $1.23675 \mathrm{E}-02$ & 0.0306 \\
\hline 114.00 & $8.77178 \mathrm{E}-03$ & 0.0334 \\
\hline 117.00 & $5.56756 \mathrm{E}-03$ & 0.0369 \\
\hline 119.25 & $2.97103 \mathrm{E}-03$ & 0.0420 \\
\hline
\end{tabular}


Table A.4. VHIHP (homogeneous compact) ${ }^{238}$ U fission. MCNP 500,000. HIST $x$-axis protile.

\begin{tabular}{|c|c|c|}
\hline$x(\mathrm{~cm})$ & Fission rate & Relative error \\
\hline 1.0 & 2.16610E-06 & 0.0902 \\
\hline 3.0 & 2.11282E-06 & 0.0921 \\
\hline 5.0 & 2.25633E-06 & 0.0900 \\
\hline 7.0 & $2.60066 \mathrm{E}-06$ & 0.0909 \\
\hline 9.0 & $2.95846 \mathrm{E}-06$ & 0.0801 \\
\hline 11.0 & $3.80131 \mathrm{E}-06$ & 0.0780 \\
\hline 13.0 & 4.37100E-06 & 0.0761 \\
\hline 15.19 & $5.00800 \mathrm{E}-06$ & 0.0622 \\
\hline 18.74 & $1.07624 \mathrm{E}-05$ & 0.0394 \\
\hline 22.05 & $9.39423 E-06$ & 0.0495 \\
\hline 24.00 & $9.00464 \mathrm{E}-06$ & 0.0496 \\
\hline 26.00 & $9.38289 \mathrm{E}-06$ & 0.0516 \\
\hline 28.00 & 8.82929E-06 & 0.0537 \\
\hline 30.00 & $8.51448 \mathrm{E}-06$ & 0.0517 \\
\hline 32.00 & $8.04442 \mathrm{E}-06$ & 0.0525 \\
\hline 34.00 & 7.78623E-06 & 0.0511 \\
\hline 36.00 & 7.58052E-06 & 0.0542 \\
\hline 37.94 & $7.13300 \mathrm{E}-06$ & 0.0570 \\
\hline 41.26 & 8.00934E-06 & 0.0450 \\
\hline 44.31 & 4.56034E-06 & 0.0718 \\
\hline 47.00 & $2.95582 \mathrm{E}-06$ & 0.0703 \\
\hline 51.00 & $2.15288 \mathrm{E}-06$ & 0.0852 \\
\hline 55.00 & $1.85263 \mathrm{E}-06$ & 0.0931 \\
\hline 59.00 & $1.23571 \mathrm{E}-06$ & 0.1163 \\
\hline 63.00 & 8.27568E-07 & 0.1324 \\
\hline 67.00 & $6.67371 \mathrm{E}-07$ & 0.1493 \\
\hline 71.00 & $4.74175 \mathrm{E}-07$ & 0.1817 \\
\hline 75.00 & $2.77738 \mathrm{E}-07$ & 0.2187 \\
\hline 80.00 & $1.68260 \mathrm{E}-07$ & 0.2280 \\
\hline 86.00 & 1.11591E-07 & 0.3198 \\
\hline 92.00 & $9.03612 E-08$ & 0.3000 \\
\hline 98.00 & $6.16314 \mathrm{E}-08$ & 0.4224 \\
\hline 104.00 & $3.34294 \mathrm{E}-08$ & 0.4949 \\
\hline 110.00 & $3.69645 \mathrm{E}-08$ & 0.8925 \\
\hline 116.45 & 5.40072E-09 & 0.9890 \\
\hline
\end{tabular}


Table A.5. VH1HP (homogeneous compact ${ }^{238} \mathrm{U}$ fission. MCNP 500,000. HIST y-axis profile.

\begin{tabular}{|c|c|c|}
\hline$y(\mathrm{~cm})$ & Fission rate & Relative error \\
\hline 2.5 & $2.37788 \mathrm{E}-06$ & 0.0728 \\
\hline 5.5 & $2.45340 \mathrm{E}-06$ & 0.0683 \\
\hline 8.5 & $2.83475 \mathrm{E}-06$ & 0.0673 \\
\hline 11.5 & $3.0193 E-06$ & 0.0631 \\
\hline 14.5 & $3.91712 E-06$ & 0.0578 \\
\hline 17.5 & $4.55584 \mathrm{E}-06$ & 0.0551 \\
\hline 20.5 & 5.20525E-06 & 0.0514 \\
\hline 23.5 & $6.49424 \mathrm{E}-06$ & 0.0463 \\
\hline 26.5 & $7.83407 \mathrm{E}-06$ & 0.0436 \\
\hline 29.5 & $6.86998 \mathrm{E}-06$ & 0.0465 \\
\hline 32.5 & $5.94661 \mathrm{E}-06$ & 0.0492 \\
\hline 35.5 & $5.55016 \mathrm{E}-06$ & 0.0514 \\
\hline 38.5 & $5.20821 \mathrm{E}-06$ & 0.0507 \\
\hline 41.55 & $6.02805 E-06$ & 0.0486 \\
\hline 45.46 & $8.48029 \mathrm{E}-06$ & 0.0401 \\
\hline 49.41 & $6.09846 \mathrm{E}-06$ & 0.0474 \\
\hline 52.5 & 5.87319E-06 & 0.0489 \\
\hline 55.05 & $6.13828 \mathrm{E}-06$ & 0.0528 \\
\hline 58.46 & $7.29245 \mathrm{E}-06$ & 0.0399 \\
\hline 61.91 & 4.68977E-06 & 0.0593 \\
\hline 65.00 & $3.04277 \mathrm{E}-06$ & 0.0623 \\
\hline 69.00 & $1.75456 \mathrm{E}-06$ & 0.0850 \\
\hline 73.00 & $1.02544 \mathrm{E}-06$ & 0.1104 \\
\hline 77.00 & $5.10828 \mathrm{E}-07$ & 0.1583 \\
\hline 81.00 & 3. $10324 \mathrm{E}-07$ & 0.1788 \\
\hline 85.00 & 2.23415E-07 & 0.2073 \\
\hline 90.00 & $1.86798 \mathrm{E}-07$ & 0.2185 \\
\hline 96.00 & $9.94652 \mathrm{E}-08$ & 0.2774 \\
\hline 102.00 & $4.30515 E-08$ & 0.4616 \\
\hline 108.00 & $1.61427 \mathrm{E}-08$ & 0.5570 \\
\hline 114.00 & $2.35496 \mathrm{E}-08$ & 0.6926 \\
\hline 126.00 & $7.18547 \mathrm{E}-09$ & 0.9880 \\
\hline 132.00 & $2.37996 \mathrm{E}-11$ & 0.0944 \\
\hline
\end{tabular}


Table A.6. VH1HP (heterogeneous compact) ${ }^{238}$ U fission. MCNP $500,000$.

HIST axial profile.

\begin{tabular}{|c|c|c|}
\hline $\mathbf{z}(\mathrm{cm})$ & Fission rate & Relutive error \\
\hline 0.75 & $3.36802 \mathrm{E}-06$ & 0.0374 \\
\hline 2.25 & $3.31456 \mathrm{E}-06$ & 0.0372 \\
\hline 3.75 & $3.28998 \mathrm{E}-06$ & 0.0369 \\
\hline 5.25 & $3.26072 \mathrm{E}-06$ & 0.0381 \\
\hline 6.75 & $3.27366 \mathrm{E}-06$ & 0.0384 \\
\hline 8.25 & $3.31738 \mathrm{E}-06$ & 0.0390 \\
\hline 9.75 & $3.09068 \mathrm{E}-06$ & 0.0379 \\
\hline 11.25 & $3.21615 \mathrm{E}-06$ & 0.0391 \\
\hline 12.75 & $3.21863 \mathrm{E}-06$ & 0.0371 \\
\hline 14.25 & $3.36033 \mathrm{E}-06$ & 0.0400 \\
\hline 15.75 & $3.35361 \mathrm{E}-06$ & 0.0380 \\
\hline 17.25 & $3.30714 \mathrm{E}-06$ & 0.0372 \\
\hline 18.75 & $3.38627 \mathrm{E}-06$ & 0.0377 \\
\hline 20.25 & $3.33761 \mathrm{E}-06$ & 0.0374 \\
\hline 21.75 & $3.37182 \mathrm{E}-06$ & 0.0372 \\
\hline 23.25 & $3.37648 \mathrm{E}-06$ & 0.0381 \\
\hline 24.75 & $3.30628 \mathrm{E}-06$ & 0.038 .5 \\
\hline 26.25 & $3.17590 \mathrm{E}-06$ & 0.0371 \\
\hline 27.75 & $3.18046 \mathrm{E}-06$ & 0.0380 \\
\hline 29.25 & $3.08967 \mathrm{E}-06$ & 0.0402 \\
\hline 30.75 & $2.92690 \mathrm{E}-06$ & 0.0388 \\
\hline 32.25 & $2.88295 \mathrm{E}-06$ & 0.0391 \\
\hline 33.75 & $2.855858 \mathrm{E}-06$ & 0.0400 \\
\hline 35.25 & $2.77913 \mathrm{E}-06$ & 0.0406 \\
\hline 36.75 & $2.77993 \mathrm{E}-06$ & 0.0405 \\
\hline 38.25 & $2.78669 \mathrm{E}-06$ & 0.0401 \\
\hline 39.75 & $2.86637 \mathrm{E}-06$ & 0.0406 \\
\hline 41.25 & $2.68017 \mathrm{E}-06$ & 0.0414 \\
\hline 42.75 & 2.69528E-06 & 0.0417 \\
\hline 44.25 & $2.84625 \mathrm{E}-06$ & 0.0428 \\
\hline 45.75 & 2.70738E-06 & 0.0420 \\
\hline 47.25 & $2.50395 \mathrm{E}-06$ & 0.0418 \\
\hline 48.75 & $2.5209 \mathrm{E}-06$ & 0.0430 \\
\hline 50.25 & 2.47725E-06 & 0.0441 \\
\hline$\$ 1.75$ & $2.35899 \mathrm{E}-06$ & 0.0455 \\
\hline 53.25 & $2.35791 \mathrm{E}-06$ & 0.0426 \\
\hline 54.75 & $2.54923 \mathrm{E}-06$ & 0.0447 \\
\hline 56.25 & $2.51891 \mathrm{E}-06$ & 0.0449 \\
\hline 57.75 & $2.26862 \mathrm{E}-06$ & 0.0440 \\
\hline 59.25 & $2.12122 \mathrm{E}-06$ & 0.0451 \\
\hline 60.75 & 2.16798E-06 & 0.0484 \\
\hline
\end{tabular}

A-7 
Table A.6. VH1HP (heterogeneous compact) ${ }^{238}$ U fission. MCNP $500,000$. HIST axial profile.

\begin{tabular}{|c|c|c|}
\hline $\mathrm{z}(\mathrm{cm})$ & Fission rate & Relative error \\
\hline 62.25 & $2.1584 .5 \mathrm{E}-06$ & 0.0491 \\
\hline 63.75 & 2.10723E-06 & 0.0478 \\
\hline 65.25 & $1.94530 \mathrm{E}-06$ & 0.0500 \\
\hline 66.75 & $1.82368 \mathrm{E}-06$ & 0.0512 \\
\hline 68.25 & $1.65011 \mathrm{E}-06$ & 0.0525 \\
\hline 69.75 & $1.66691 \mathrm{E}-06$ & 0.0578 \\
\hline 71.25 & $1.482 .58 \mathrm{E}-06$ & 0.0556 \\
\hline 72.75 & $1.41074 E-06$ & 0.0596 \\
\hline 75.00 & 1.18372E-06 & 0.0575 \\
\hline 78.00 & 9.20175E-07 & 0.0637 \\
\hline 81.00 & $6.33224 \mathrm{E}-07$ & 0.0730 \\
\hline 84.00 & $5.17586 \mathrm{E}-07$ & 0.0811 \\
\hline 87.00 & 4.24860E-07 & 0.0881 \\
\hline 90.00 & $2.90078 \mathrm{E}-07$ & 0.1109 \\
\hline 93.00 & $2.18486 \mathrm{E}-07$ & 0.11 .56 \\
\hline 96.00 & $1.54131 \mathrm{E}-07$ & 0.1287 \\
\hline 99.00 & $1.00053 \mathrm{E}-07$ & 0.1518 \\
\hline 102.00 & $6.72258 \mathrm{E}-08$ & 0.1804 \\
\hline 105.00 & $5.46317 \mathrm{E}-08$ & 0.2032 \\
\hline 108.00 & $3.69207 \mathrm{E}-08$ & 0.2383 \\
\hline 111.00 & $3.63428 \mathrm{E}-08$ & 0.2775 \\
\hline 114.00 & $2.95006 \mathrm{E}-08$ & 0.3151 \\
\hline 117.00 & 2.06862E-08 & 0.3709 \\
\hline 119.25 & $1.96888 \mathrm{E}-08$ & 0.3930 \\
\hline
\end{tabular}




\section{INTERNAL DISTRIBUTION}

1. S. J. Ball

2-6. F. C. Difilippo

7. D. T. Ingersoll

8. S. Martin

9. G. E. Michaels

10. C. E. Oliver

11. C. E. Pugh

12. J. P. Renier

13. P. L. Rittenhouse
14. R. C. Ward

15-19. B. A. Worley

20. EPMD Reports Office

21-22. Laboratory Records Department

23. Laboratory Records, ORNL-RC

24. Document Reference Section

25. Central Research Library

26. ORNL Patent Section

\section{EXTERNAL DISTRIBUTION}

27. L. D. Mears, Gas Cooled Reactor Associates, 10240 Sorrento Valley Road, Suite 300, San Diego, CA 92121-1605.

28. G. C. Bramblett, GT-MHR Project Division, P.O. Box 85608, San Diego, CA 92186-9784.

29. D. Pettycord, GT-MHR Plant Design, Control Office-West, c/o General Atomics, P.O. Box 85608, San Diego, CA 92186-9784.

30. B. Demars, U.S. Department of Energy, Naval Reactors Office (NE-60), 3N06/NR Crystal City, Arlington, VA 22202.

31. P. M. Williams, Office of Nuclear Energy, U.S. Department of Energy, NE-42/GTN, Washington, DC 20585.

32. S. A. Caspersson, ABB/CENP, M/S 9354-0422, 1000 Prospect Hill Road, Windsor, CT 06095-0500

33. R. R. Mills, PDCO-East, 3206 Tower Oaks Blvd., Suite \#300, Rockville, MD 20852-4220.

34. S. K. Ghose, Bechtel National Laboratory, P.O. Box 193965, 1507, San Francisco, CA 94119.

35. W. J. Parker, Stone \& Webster Engineering. 245 Summer Street, F.O. Box 2325, Boston, MA 02107.

32-34. Office of Scientific and Technical Information, U.S. Department of Energy, P.O. Box 62, Oak Ridge, TN 37831.

35. GT-MHR Plant Design, Control Office-East, Attention: R. R. Mills, MEREX, Inc., 3206 Tower Oaks Boulevard \#300, Rockville, MD 20852.

36. P. J. Karcz, Office of Nuclear Energy, U.S. Department of Energy, NE-42/GTN, Germantown, MD 20585.

37. D. J. Krommenhoek, Knolls Atomic Power Laboratory, Bldg. D-2, Rm. 121, P.O. Box 1072 , Schenectady, NY 12301.

38. R. Brogli, Paul Scherrer Institute, Wurenlingen und Villigen, CH-5232 Villigen PSI, Switzerland.

39. J, C. Cleveland, International Atomic Energy Agency, POB 100, A-1400, Vienna, Austria.

40. R. W. Brockett, Harvard University, Pierce Hall, 29 Oxford Street, Cambridge, MA 02138.

41. D. J. Dudziak, Department of Nuclear Engineering, 110B Burlington Engineering Labs, North Carolina State University, Raleigh, NC 27695-7909.

42. J. E. Leiss, Rt. 2, Box 142C, Broadway, VA 22815.

43. N. Moray, Department of Mechanical and industrial Engineering, University of Illinois, 1206 West Green Street, Urbana, IL 61801.

44. M. F. Wheeler, Department of Mathematics, Rice University, P.O. Box 1892, Houston, TX 77251.

45. Office of Assistant Manager for Energy Research and Development, Department of Energy, Oak Ridge Operations Office, P.O. Box 2008, Oak Ridge, TN 37831. 

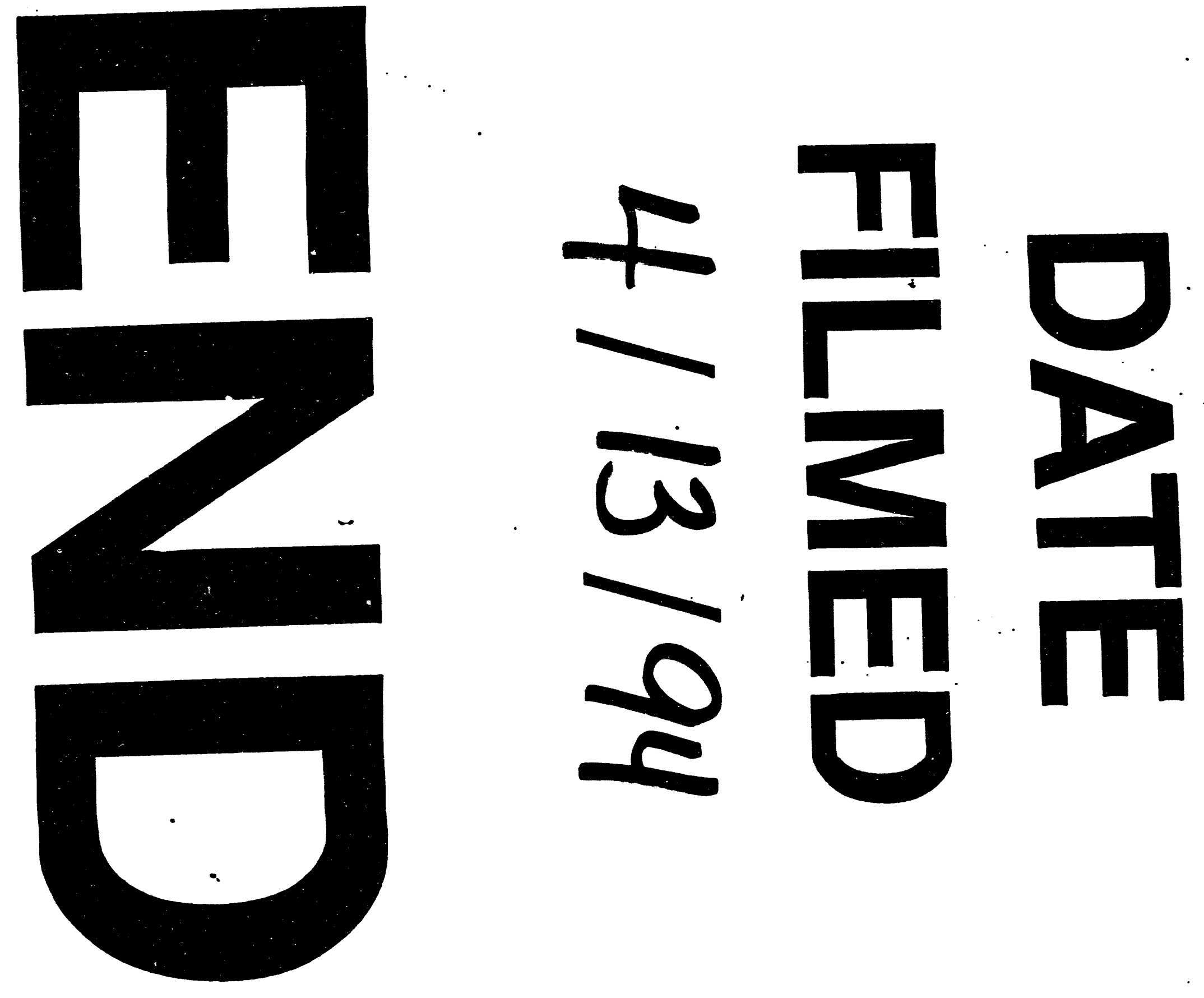


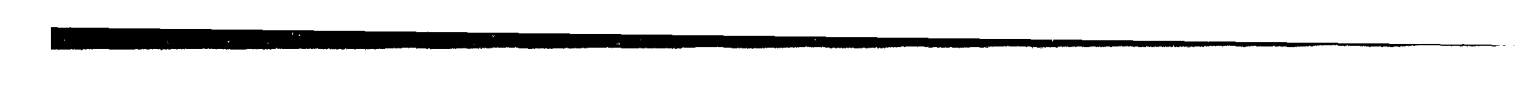

